\title{
The Political Geography of Government Formation: Why Regional Parties Join Coalitions*
}

\author{
Albert Falcó-Gimeno \\ University of Barcelona
}

Forthcoming in Party Politics

\begin{abstract}
Political parties differ in the geographic distribution of their support. This paper argues that a territorially uneven distribution of a party's votes facilitates its participation in government, because it produces a tendency to prioritize demands for locally-targeted goods that are more conducive to the negotiation of reciprocal logrolling agreements with potential partners. Using a measure based on the Gini coefficient, I empirically evaluate the extent to which the geographic concentration of votes plays a role in the formation of governments, taking Spanish local elections from 1987 to 2011 as a testbed. With around 500 formation opportunities and 20,000 potential governments, multinomial choice models are estimated (conditional and mixed logits) and a very sizable effect is documented: a one-standard-deviation increase in the electoral geographic concentration of a potential government almost doubles the likelihood of its formation. These findings are relevant for students of government formation, regional parties, and political geography.
\end{abstract}

* Support for this research was provided by the Spanish Ministry of Economy and Competitiveness through the research grant CSO2013-42262-P. 


\section{Introduction}

The geographical distribution of votes across the territory conditions many facets of the political process, including the configuration of party systems, parties' electoral success, and resource allocation in the making of policies. And yet, we know little about whether and how political geography shapes one of the cornerstones of representative democracies: the formation of governments.

A perennial question in the study of government formation processes is 'who gets in', which is particularly relevant in multiparty PR systems, where situations in which no single party controls the majority of parliamentary seats are most common. In these contexts, elections determine parliaments but do not decide on the composition of the government, which has to be settled in negotiations between parties, commencing once all votes have been tallied. In such bargaining processes many elements come into play, not only election results. In fact, previous studies have found a surprisingly poor correlation between the fate of politicians and parties in office and the evolution of their electoral fortunes (Cheibub and Przeworski, 1999; Mattila and Raunio, 2004; Maravall, 2007, 2010). Other additional factors, therefore, must hold the key to explaining participation in government.

From the many studies that have examined the determinants of a party's chances of joining government, size and ideology emerge as the most influential factors. In a nutshell, parties that are larger, and more closely identified with the median in the predominant ideological dimension, are more likely to succeed (e.g. Warwick, 1996; Martin and Stevenson, 2001; Mattila and Raunio, 2004; Isaksson, 2005; Indridason, 2011; Savage, 2014). Other factors, such as greater internal democracy (Bäck, 2008), links to past authoritarian regimes (Druckman and Roberts, 2007), or withdrawals from previous coalitions (Tavits, 2008), have been found to have a negative effect, hindering a party's prospects of gaining access to government. The effect of incumbency, meanwhile, appears to be contingent on other institutional and party-level factors (Martin and Stevenson, 2010). In general, it seems that while incumbent governments are better positioned to (re-)form, incumbent parties, on the other hand, tend to be disadvantaged (Glasgow and Golder, 2015).

All these notwithstanding, parties also differ in the extent to which their votes are either geographically concentrated or, rather, homogeneously distributed across the territory. Previ- 
ous research has shown that regional parties, with territorially concentrated electorates, tend to focus primarily on securing benefits particular to their region in order to satisfy their clienteles (Kitschelt, 2000; Heller, 2002; Kellam, 2015). While evidence has accrued to demonstrate the success of such policies (e.g. De Winter and Tursan, 1998), we know much less about whether and why these parties become partners in governments.

This paper considers the role of political geography in government formation processes. I argue that the territorial distribution of a party's votes will shape its attractiveness as a potential coalition partner. Regionalized parties (i.e. those with an uneven distribution of votes across the territory), the argument goes, will have geographically targeted interests that can be more easily accommodated in the bargaining process leading to the formation of a government than parties that make broader, more programmatic, demands.

The paper contributes to existing scholarly research on three different streams of analysis. Firstly, it enhances previous literature by focusing on the role of the geographic distribution of parties' support: a variable that has been found to greatly influence the dynamics of political competition and policy-making, but has been overlooked in the study of government formation. Secondly, the paper also communicates to scientific research interested in the role that regional parties play in democracies by focusing on their capacity to take part in government coalitions. Finally, this work also contributes to the stream of literature that has studied the political effects of electoral geography by highlighting, in particular, the consequences it may have for the formation of governments in parliamentary democracies.

\section{The Argument}

The geographical distribution of political preferences has profound consequences on various aspects of political competition. The number of parties that compete, the platforms that they choose, the likelihood of electoral success, and even the choice of electoral institutions, can all be greatly conditioned depending on whether there is a symmetric or asymmetric distribution of preferences across a territory (Rodden, 2010).

A recently developed body of research examines the effect of the geographic concentration of voter preferences on the level and composition of public spending (e.g. McGillivray, 2004; Rickard, 2012; Jurado, 2014; Jusko, 2015; Jurado and León, 2016). In general, these studies find 
that the territorial distribution of voters interacts with electoral rules in shaping policy-making: resource allocation in majoritarian systems appears to be more sensitive to variations in the geographic clustering of the electorate than in PR systems. Nonetheless, political geography also seems to matter in the latter, where increasing geographic concentration curbs spending on universalistic policies to the benefit of particularistic projects.

Whether voters with similar political preferences are clustered in certain areas, or homogeneously spread across a territory, has consequences, not only for the political system as a whole, but also for individual political parties. Within the same party system, parties can differ in the geographic distribution of their support. Some have geographically concentrated electorates whereas the supporters of other parties are widely dispersed. I claim that the former will respond to narrower interests than the latter and, therefore, will have different relative preferences as between particularistic and universalistic (programmatic) policies. Since the geographical targetability of certain goods is higher than others, the electoral geography of a party will have an impact on the demands it makes in the context of negotiating a coalition agreement.

My argument builds upon two clusters of claims and findings from previous studies. Firstly, politicians with strongly regionalized bases of support are said to have higher incentives to provide particularistic (pork-barrel) spending projects to the regions in which they are electorally strong (aka, bringing home the bacon). When the voters of a party are geographically dispersed, on the other hand, the electoral returns for spending on these kinds of projects are low compared to spending on other (non-geographically-targeted) goods. This argument can be found, for instance, in Jurado (2014), who argues that as the electoral support of a party becomes more concentrated in specific areas of a territory, so the party is compelled to resort to particularistic, locally-honed policies with which they can more efficiently target their voters. On the contrary, for parties that obtain a similar level of electoral support across the territory, the incentives will be to pursue policies that spread benefits to voters, without geographic discrimination.

Secondly, and consequently, where parties differ in their preferences for certain types of goods depending on the geographic distribution of their support, they are also likely to diverge in the types of demands they make when bargaining over the formation of a new government. I contend that the presence of parties with stronger preferences for narrow, geographically- 
defined, policies eases coalition negotiations. This argument has previously been made in studies of coalition-building processes in the US Congress. Geographically-targeted projects are traded on a logrolling basis to satisfy coalition members' geographically-defined interests (Mayhew, 1974), but they also grease the wheels more generally, helping to construct coalitions between political actors with and without geographically narrow preferences that secure legislative packages that also include "general benefit legislation" (e.g. Evans, 1994, 2004; Ellwood and Patashnik, 1993; Ferejohn, 1974). ${ }^{1}$

While most of these arguments speak to the formation of coalitions between individual legislators, an analogous case can be made for negotiations between parties in multi-party legislatures. Recently, Kellam (2015) has applied this idea to coalition politics in Latin American presidential systems. She argues that parties oriented towards particularistic goods "hire out" their support to the President in exchange for locally-targeted policies. That, according to Kellam, reduces the price of these parties as potential coalition partners and provides presidents with coalitional flexibility. In a similar vein, others have made this general argument in relation to parliamentary systems. Heller (2002), for instance, focuses on policy exchanges between parties in Spain, claiming that, because their primary focus is on their own regions rather than the whole country, parties with a regionalized support seek a different set of rewards than national parties, and that "opens the door to policy-making bargains that would be unavailable to national parties alone." (Heller, 2002, 660-661).

However, we can also apply this argument specifically to the government formation processes that occur in parliamentary systems. Parties with particularistic preferences should become attractive bedfellows from the point of view of a potential coalition partner, because they can be satisfied with some locally-targeted spending, leaving the rest of resources available to pursue any other kind of program without having to share the credit. Geographically narrow interests, therefore, increase the compatibility of parties' demands in terms of electoral creditclaiming, thereby making access to government more likely for those parties with territorially concentrated electorates. This argument complements the idea that 'preference tangentiality' between parties, namely, parties whose salient interests do not overlap with each other, increases their compatibility and makes reaching compromises easier because their demands fit better

\footnotetext{
${ }^{1}$ There is also experimental evidence indicating that the availability of private goods to distribute among legislators helps to reach legislative compromise (see for instance Christiansen et al., 2014).
} 
together (Luebbert, 1986; Falcó-Gimeno, 2014). In this case, the geographical concentration of parties' support would make their territorial interests more tangential, their demands more compatible, and therefore, should facilitate coalition-building. This compatibility can take two different forms. On the one hand, the locally-targeted demands of a territorially-concentrated party are likely to be compatible with the preferences of another (programmatic) party that has a more homogeneously distributed basis of support, who seeks to advance its own generalinterest policy agenda. On the other hand, the geographically narrow interests of a party might also be compatible with those of another party whose interests are concentrated in a different part of the territory. It is beyond the scope of this paper to generate a clear-cut prediction on which of these two types of compatibility is more likely to crystallize into a new government, or in which circumstances one or the other formation is more probable. ${ }^{2}$ The main theoretical expectation of this paper is that, on average, increasing geographic concentration will make government participation more likely, ceteris paribus.

\section{Measurement}

I have argued that the electoral geography of the party is tightly connected to the intensity of preference for particularistic goods and that, in turn, should map to the government formation process. Therefore, to estimate the effect of the territorial distribution of a party's votes on its chances of participating in government, a measure of the geographic asymmetry of parties' electoral support is first needed. This is what I will call an index of geographic concentration. To accomplish that I have relied on a measure used in the literature on the nationalization of party systems, which is based on the Gini coefficient of the inequality of parties' vote shares across different territorial units. The standard Gini coefficient, however, does not correct the potential bias coming from the unequal size of the territorial units within a given polity or the unequal number of units across polities, in measuring the regional heterogeneity of parties' votes (Bochsler, 2010). This is why I use Bochsler's 'standardized Party Nationalization Score' (sPNS), that takes both factors into account, to measure the extent to which the electoral strength of a party is evenly distributed across the territory, ranging from 0 (maximum region-

\footnotetext{
${ }^{2}$ The specific types of policies that fall under the competence of the government, which may be different in different contexts, or the financial tensions that the government has to face, are likely to make a difference in this regard.
} 
alization) to 1 (maximum nationalization). I then simply invert the sPNS score (subtract it from 1) in order to produce a Geographical Concentration Index (GCI). The formula is the following: ${ }^{3}$

$$
G C I_{j}=1-\left(2 \cdot \frac{\sum_{i=1}^{U}\left(v_{i} \cdot\left(\sum_{i=1}^{U} v_{j i}-\frac{v_{j i}}{2}\right)\right)}{\sum_{i=1}^{U} v_{i} \cdot \sum_{i=1}^{U} v_{j i}}\right)^{\frac{1}{\log \left(\frac{\left(\sum_{i=1}^{U} v_{i}\right)^{2}}{\sum_{i=1}^{U} v_{i}^{2}}\right)}}
$$

where $v_{j i}$ refers to the number of voters of party $j$ in the territorial unit $i$ in a polity with a total of $U$ units, ordered according to the increasing vote share of party $j .{ }^{4}$

Table 1 shows the scores of the GCI in three stylized scenarios in which a total of 300 votes are cast in three different territorial units (100 votes in each). In all three hypothetical cases, parties $A, B, C$, and $D$ have obtained a total of $120,90,45$, and 45 votes, respectively. In scenario (a) all four parties have a fairly even distribution of the voters across tracts, whereas in scenario (b) parties have specific territorial strongholds as well as places where their support is scarce. Scenario (c), on the other hand, depicts an intermediate situation where one party $(D)$, is clearly more geographically polarized than the rest. The GCI, as shown, captures these party differences.

Table 1. Stylized Scenarios of Electoral Geographies

\begin{tabular}{|c|c|c|c|c|c|}
\hline & \multicolumn{3}{|c|}{ Terr. Units } & \multirow{2}{*}{ GCI } \\
\hline & & 1 & 2 & 3 & \\
\hline \multirow{4}{*}{ 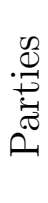 } & A & 40 & 39 & 41 & .0231 \\
\hline & B & 30 & 31 & 29 & .0308 \\
\hline & $\mathrm{C}$ & 15 & 16 & 14 & .0611 \\
\hline & D & 15 & 14 & 16 & .0611 \\
\hline
\end{tabular}

(a) Homogenous scenario

\begin{tabular}{|c|c|c|c|c|c|}
\hline & \multicolumn{3}{|c|}{ Terr. Units } & \multirow{2}{*}{ GCI } \\
\hline & & 1 & 2 & 3 & \\
\hline \multirow{4}{*}{ 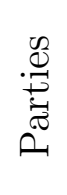 } & $\mathrm{A}$ & 40 & 10 & 70 & .5725 \\
\hline & B & 30 & 55 & 5 & .6208 \\
\hline & $\mathrm{C}$ & 25 & 0 & 20 & .6208 \\
\hline & $\mathrm{D}$ & 5 & 35 & 5 & .7083 \\
\hline
\end{tabular}

(b) Polarized scenario

\begin{tabular}{|c|c|c|c|c|c|}
\hline & \multicolumn{3}{|c|}{ Terr. Units } & \multirow{2}{*}{ GCI } \\
\hline & & 1 & 2 & 3 & \\
\hline \multirow{4}{*}{ 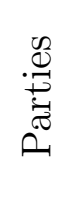 } & $\mathrm{A}$ & 45 & 30 & 45 & .1667 \\
\hline & B & 35 & 25 & 30 & .1490 \\
\hline & $\mathrm{C}$ & 15 & 10 & 20 & .2854 \\
\hline & $\mathrm{D}$ & 5 & 35 & 5 & .7083 \\
\hline
\end{tabular}

(c) Mixed scenario

Note: Entries are numbers of votes.

\footnotetext{
${ }^{3}$ See Bochsler $(2010,164)$, who uses a slightly different notation.

${ }^{4}$ As shown later, the empirical results are robust to the use of other indices to measure the regionalization of parties' vote shares.
} 


\section{Research Design}

\subsection{The local level as a testbed}

The empirical analyses of this paper are run on a sample of Spanish local governments; specifically from the region of Catalonia. In contrast to most of the studies cited above that refer to nationwide coalition-building processes, then, this paper will focus on the municipal level and consider each municipality as an independent polity. The paper studies the formation of governments in a large number of Spanish municipalities and measures the level of geographical concentration of each party within each municipality. That is, I will test the extent to which parties that are strongly regionalized in specific parts of a municipality are more likely to participate in its local government (rather than analyze how regional parties, at the national level, perform in government formation processes at the local level).

The empirical assessment of general theories of coalition formation and stability using data on local governments in one single country is quite standard (e.g. Bäck (2003, 2008) in Sweden, Blockmans et al. (2016) in Belgium, Daniele et al. (2017) in Italy, Debus and Gross (2016) in Germany, Laver et al. (1987) in the UK, Fujiwara and Sanz (2017) in Spain, Serritzlew et al. (2010) and Skjaeveland et al. (2007) in Denmark, or Steunenberg (1992) in the Netherlands). The case made for using local data in these studies is, in general, that "the analysis of local coalitions within a single country holds constant the two key variables of time and polity. This allows for the testing of theories adapted to the specific situations of particular coalition systems while still retaining sufficient cases to conduct a useful analysis." (Laver et al., 1987, 503). In the case of this paper, the requirements that should be met for the theory to travel well to the local level would be that 1) local governments have a variety of policies at hand that can be broadly characterized as more or less geographically-targeted/universalistic and thus, given budget constraints, that a trade-off exists between them to cater to geographically concentrated or dispersed constituencies; 2) political competition in local elections is to a certain extent structured around which of these policies parties defend for the municipality; and 3) the local government is clearly identifiable and its formation typically requires a bargaining process between political parties. In the following I defend why the Spanish local level is a particularly suitable testing ground that meets these criteria. 
Firstly, Spanish municipal executives are legally obliged to provide a wide range of public services, which increase with the municipality's size: "all municipalities are responsible, as a minimum, for the provision of public lighting, a cemetery, waste collection, street care and cleaning, water, sewerage services, and food safety. In addition, municipalities with a population greater than 5,000 residents are also responsible for the provision of public parks, a public library, a market, and waste treatment. Beyond that, municipalities with a population greater than 20,000 residents are also responsible for the provision of civil defence, social services, fire services, and sport facilities. Municipalities with a population greater than 50,000 residents are also responsible for the provision of public transport and environmental protection." (Villata Puig, 2013, 289). Also, municipalities can provide further services in areas like education, culture, gender equality, housing, health, and environmental protection, in coordination with the regional and central governments, and, although they are not able to establish new taxes, they are responsible for administering and can increase/decrease a number of taxes affecting business, real estate, vehicle property, construction, among others. The competences of Spanish local governments are therefore multi-purpose, with the major budgetary items corresponding to policy responsibilities traditionally assigned to the local public sector: environmental services, urban planning, transport, welfare and social services, etc. (Solé-Ollé, 2006). That includes, therefore, pork-barrel geographically-targeted spending (e.g. lighting and paving) as well as general-interest policies (e.g. refuse collection and treatment, home healthcare services, or certain taxes). To the extent that the variation in the policies available for local governments can be thought of as continuum from geographically-targeted to more universalistic policies, the context is appropriate to test the general argument presented here. Of course, some universalistic policies at the local level have geographically narrow implications and, to the same extent, policies targeted at specific areas within the municipality also have spillovers for the rest of its territory. Nonetheless, the geographical consequences of paving a particular street in a particular neighborhood as opposed to increasing certain business taxes seem clearly different.

Secondly, this wide array of competences implies that government formation processes at the Spanish municipal level are politically relevant and their outcomes are certainly consequential for citizens' lives. As a result, local issues play an important part in the electoral competition happening in Spanish municipal elections, where the contextual factors and shortcuts that 
shape voting behavior are singular to the local arena and different from those that tend to operate in general or regional elections (Barberá, 2010; Riera et al., 2016, 2017; Skrinis and Teperoglou, 2008).

Thirdly, the process that leads to the formation of a government in Spanish municipalities mirrors that of many parliamentary democracies: a vote of investiture is held to elect the mayor, who has to obtain the absolute majority of positive votes from the municipal plenary (i.e. the parliament). ${ }^{5}$ The mayor, then, allocates policy responsibilities to those councillors that will form the municipal government, much like ministers in national governments.

As said, focusing on local governments in one particular country keeps many economic, social, cultural, and institutional differences constant as compared to cross-national studies, while at the same time gives scope for a large number of observations. As usual, this internal validity advantage comes, of course, at the expense of external validity. However, given that Spanish local governments very much resemble executives at other administrative levels in terms of the type and importance of their policy remits, there are reasons to believe that the lessons we can derive from this study apply far beyond Spain and are not simply idiosyncratic to its local institutions.

\subsection{Data}

In terms of data, I rely on two different sources. Firstly, I leverage the census tract-level data that the Spanish Ministry of Interior makes publicly available in its website. ${ }^{6}$ In this database one can find the exact vote counts of all running parties in each census tract for all elections since 1987. I specifically use data from the seven local elections held in Spain from 1987 to 2011 to elect representatives at municipal council level.

Secondly, I also use Martínez Farrero's (2015) data on the formation of local governments in 131 municipalities of one particular region of Spain: Catalonia, from 1983 to 2011. From the 947 municipalities existing in the region, Martínez Farrero selected the 131 with more than 10,000 inhabitants in 2011. Thus, they were not selected on the basis of the type of government formed, i.e., the dependent variable. The government formation processes of these selected

\footnotetext{
${ }^{5}$ If the vote is lost, the head of the party with the highest number of votes is automatically elected mayor. Nonetheless, the formation of coalitions typically involve that the mayor is elected in the first vote of investiture.

${ }^{6} \mathrm{http}: / /$ www. infoelectoral.interior.es. Corrections of some typographical errors in the recording of actual votes have been made by the author.
} 
municipalities were then traced back to 1987 (regardless of the evolution of the number of inhabitants). It bears mentioning that the identification of the parties that are members of the government is based on whether or not they hold portfolios with specific policy remits attached to them (i.e. councillorships with policy responsibilities) and that only postelection governments are coded. Subsequent government changes during the term are, hence, not considered in this database.

Table 2 offers some descriptive information on these governments. $38 \%$ of them were formed in situations in which a single party obtained the absolute majority of seats in the local parliament. That leaves around 500 governments formed in situations of parliamentary minority, and it is these I will look at in the empirical analyses; where actual negotiations between parties over the formation of a new government take place. ${ }^{7}$ In these contexts, coalition governments formed in more than $3 / 4$ of the formation opportunities and $30 \%$ did not secure a majority of seats. More than half of the sample governments were minimum winning coalitions, and only $17 \%$ were oversized. The average government in a minority situation included more than 2 parties and a total seat share of around 55\%. Finally, the largest party in parliament was a member of the cabinet in the overwhelming majority of cases (87\%), and at least one of the parties in office had participated in the preceding government on more than $2 / 3$ of the occasions. Nonetheless, less than $20 \%$ of the governments formed held power over two consecutive terms with the same partisan composition. ${ }^{8}$

In the particular context of these data, the geographical concentration index averages 0.075 across the 3,900 party-municipality-election observations for which we have information, and it displays a rather right-skewed distribution (skewness $=4.6$ ), much like most measures of regionalization at the party level. ${ }^{9}$ The descriptive statistics are offered in Table 3. Reassuringly, the GCI strongly correlates with more traditional indexes of distributional inequality, such as the Gini index -used in reversed form in Jones and Mainwaring (2003) as a score of party nationalization- $(r=.791 ; p<.001)$.

\footnotetext{
${ }^{7}$ The results that will be presented below, though, do not hinge on this decision. Including majority situations in the analyses - under which (surplus) coalition governments do also form $1 / 4$ of the times- yields essentially the same conclusions.

${ }^{8}$ It should be noted that incumbency here refers to the previous postelection government, which might in some cases be different than the actual outgoing government.

${ }^{9}$ Note that if we take the square root of the GCI to increase the normality of the distribution, significantly reducing right-skewness (down to a value of 2.0), and use it for the analyses, there is no consequential change in the results presented below.
} 
Table 2. Descriptive Statistics of Governments

\begin{tabular}{rccccccccc}
\hline & \multicolumn{4}{c}{ All situations } & \multicolumn{4}{c}{ Minority situations } \\
& Mean & SD & p50 & N & Mean & SD & p50 & N \\
\hline Absolute Majority & 0.38 & 0.48 & 0 & 860 & - & - & - & - \\
Coalition & 0.58 & 0.49 & 1 & 860 & 0.78 & 0.42 & 1 & 536 \\
Minority Government & 0.18 & 0.39 & 0 & 860 & 0.30 & 0.46 & 0 & 536 \\
Minimum Winning Coalition & 0.33 & 0.49 & 1 & 860 & 0.54 & 0.50 & 1 & 536 \\
Surplus Coalition & 0.20 & 0.40 & 0 & 860 & 0.17 & 0.37 & 0 & 536 \\
N. of Parties & 1.87 & 0.92 & 2 & 860 & 2.21 & 0.90 & 2 & 536 \\
Total Seat Share & 58.0 & 12.1 & 54.5 & 860 & 55.1 & 12.1 & 52.9 & 536 \\
Largest Party In & 0.92 & 0.27 & 1 & 860 & 0.87 & 0.33 & 1 & 536 \\
Any Incumbent Party In & 0.77 & 0.42 & 1 & 748 & 0.70 & 0.46 & 1 & 490 \\
Incumbent Government & 0.32 & 0.47 & 0 & 748 & 0.19 & 0.39 & 0 & 490 \\
\hline
\end{tabular}

Table 3. Descriptive Statistics of GCI

\begin{tabular}{ccccccccc}
\hline & Mean & SD & p10 & p50 & p90 & Min & Max & N \\
\hline GCI & .075 & .064 & .030 & .060 & .127 & .001 & .779 & 3900 \\
\hline
\end{tabular}

Finally, to get a clearer sense of how the geographical concentration measure works, Figure 1 maps the actual territorial distribution of the vote of two parties in the municipality of Torroella de Montgrí in the 2011 local elections. In this municipality of about 11,000 inhabitants, 17 representatives were elected. None of the parties obtained a sufficient majority to form a government on its own. The winning party won 5 seats $(\mathrm{CiU})$; the second largest obtained 4 (ERC); L'Estartit Som Tots (LEST) and Unitat i Progrés Municipal - Progrés Municipal (PSC) won 3 apiece, whereas two other parties obtained 1 each (COET and PP). As this figure shows, LEST and PSC obtained similar vote shares and the same number of seats in the local parliament, but they differed markedly in the territorial distribution of their votes. Whereas PSC obtained vote shares of between 15 and 22 percent in all census tracts (except just one, where it got $7 \%$ of the votes), LEST received the lion's share of its electoral force in one particular stronghold: more than $60 \%$ of the votes cast in the census tract where l'Estartit belongs (a village within the territory of Torroella de Montgrí), were for LEST. In the rest of the census tracts, though, the party obtained an average of only $4 \%$ of the votes. As a result, on the index of geographical concentration, LEST scores about four times higher than PSC 
Figure 1. Examples of Parties with High and Low Geographical Concentration in the Same Municipality (Torroella de Montgrí 2011)
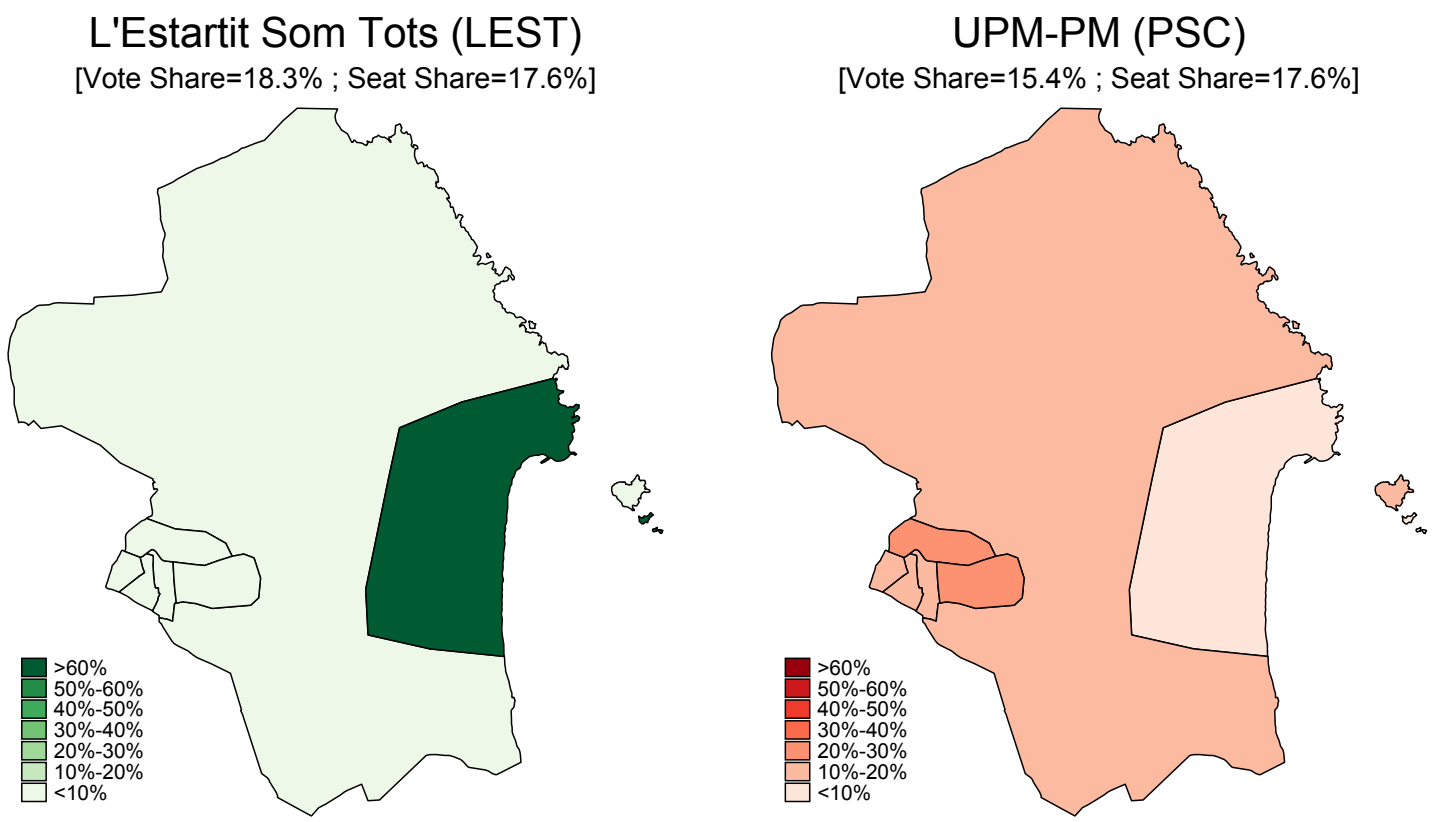

Note: The Geographical Concentration Index (Reverse Standardized Party Nationalization Score) in this case scores 0.428 for LEST and 0.114 for PSC. This means that the geographical concentration of LEST's votes is around four times higher than that of PSC's support.

(0.428 and 0.114 , respectively). Interestingly, the postelection bargaining process in this case ended up with $\mathrm{CiU}$, the largest party, proposing a minimum winning coalition to LEST and PP, which reached the necessary majority of 9 seats $(5+3+1)$. LEST and not PSC, therefore, made its way into office and gave its support to the investiture of CiU's candidate for mayor.

\section{$5 \quad$ Empirical Analysis}

\subsection{Baseline models}

As is standard practice in statistical analyses of government formation, I employ multinomial choice models where the units of analysis are defined as formation opportunities, and potential governments as choice alternatives (Martin and Stevenson, 2001; Bäck, 2003; Diermeier and Merlo, 2004; Druckman et al., 2005; Warwick, 2005; Golder, 2006; Skjaeveland et al., 2007; Bäck and Dumont, 2008; Indridason, 2008; Kang, 2009; Martin and Stevenson, 2010). It has been claimed that these types of models are most appropriate to study the determinants of parties' likelihood to join governments, rather than binary choice models, in order to control 
for coalition-level effects: "analysts should use the government formation opportunity as the unit of analysis even if the question of interest centers on parties." (Glasgow and Golder, 2015). Therefore, the analyses presented below use conditional logits as well as mixed logits (see Glasgow et al., 2012). ${ }^{10}$ The variation that is going to be exploited is, therefore, within formation opportunity, implying that there is no reason to be concerned about potential sources of heterogeneity across municipalities or time that might correlate with parties' geographical concentration, raising a threat to causal identification.

Given that the observations are not parties but potential governments, the party-level variables in the model specifications can represent either the presence or the amount of that variable in the potential government. Party size, for instance, is accounted for in the model through a dummy indicating whether or not the potential government includes the largest party in parliament, the total Seat Share of the government, and its second power (Seat Share $\left.{ }^{2} / 100\right)$ to account for non-linear effects (divided by 100 to make the scale of the estimated coefficient more similar to the rest). Incumbent Party and Incumbent Mayor, on the other hand, take value 1 if the potential government contains at least one party that was in the previous one, and the previous mayor's party, respectively, and 0 otherwise.

With respect to key explanatory factor (a continuous variable at the party-level), its representation at the potential government level takes into account how the additional geographical concentration a party brings to the government changes the coalition as a whole (Glasgow and Golder, 2015). In contrast to additional seats (which may have a non-linear impact on the chances of formation of the coalition), there is nothing in the argument above that makes us expect anything different than a monotonically (linear) positive effect of geographical concentration. Hence, the variable is represented at the government level adding up the GCIs of the parties forming the coalition. Additionally, I show further on that the results are robust when alternative aggregation techniques are applied, such as the arithmetic and weighted averages of the coalition members' GCIs. Besides, it is true that there is a relevant, substantive difference between a potential government in which two parties have their respective territorial strongholds, on the one hand, and the scenario in which one party has an even distribution of the vote while the other is geographically concentrated, on the other. In the former, both par-

\footnotetext{
${ }^{10}$ For reassurance, I run a series of robustness tests with binary logits where parties are the observations. The coefficient estimates of the geographical concentration index are positive and statistically significant $(p<.05)$.
} 
ties would have narrow geographic interests in two different parts of the territory. In the latter, according to our argument, the two parties would have different types of preferences in terms of locally-targeted goods vs. general-interest policies. The form of compatibility between the demands of the two parties would be different in each scenario, but we do not have any specific expectation as to which of the two governments would be more likely to form. Therefore, since it is, in any case, clear that we expect increasing geographic concentration to make a single party more likely to participate in government -assuming the nature of the potential partners remains constant- we stick with the above-mentioned aggregation strategy. In addition, the Appendix shows that variance in the GCIs of the parties in the potential government does not significantly affect the likelihood of formation. ${ }^{11}$

Table 4 presents the estimations yielded by the statistical analyses, following Glasgow and Golder's (2015) model specifications. ${ }^{12}$ The exponentiated coefficients reported in Table 4 and the coefficient estimates plotted in Figure 2 show that our results for the formation of local governments in Catalonia accord with the main findings of previous studies. Larger parties are more likely to join a government, although the effect of size is marginally decreasing. The effect of incumbency, on the other hand, has two clearly differentiated sides. Incumbent governments are around five times more likely to form anew than any other government but, controlling for the latter, having been a member of the previous government negatively impacts on the likelihood of joining the next government. The same goes for the incumbent mayor's party. Also, minimum winning coalitions and governments with fewer parties are more likely to form than minority governments and governments with a larger number of parties.

The fact that these results closely match findings from previous studies is indeed reassuring. However, this paper is mainly concerned with the effect of the territorial distribution of the vote on government formation processes. The models presented in columns 3 and 4 yield positive and strongly statistically significant coefficient estimates of Geo. Concentration (GCI). Specifically, a one-standard-deviation increase in the government's GCI yields a $97 \%$ boost in the chances

\footnotetext{
${ }^{11}$ More specifically, a variable measuring the standard deviation of parties' GCIs in the potential government is introduced in the baseline model both additively and in interaction with overall GCI. None of the effects is significantly different from zero as Table A.1 in the appendix shows.

${ }^{12}$ In column 4 I relax the independence of irrelevant alternatives assumption and employ a mixed logit with random coefficients (Glasgow et al., 2012). The McFadden and Train's (2000) Lagrange multiplier test determines that estimating a model with random coefficients for a few variables would fit the data better, but the final analysis yields very similar results both for geographical polarization and the control variables. If anything, it estimates a larger impact of the former.
} 
Table 4. Coalition Formation \& Geographical Concentration Conditional and Mixed Logits

\begin{tabular}{|c|c|c|c|c|c|}
\hline & $\begin{array}{l}\text { clogit } \\
(1)\end{array}$ & $\begin{array}{l}\text { clogit } \\
(2)\end{array}$ & $\begin{array}{l}\text { clogit } \\
(3)\end{array}$ & $\begin{array}{l}\text { mixec } \\
\text { mean }\end{array}$ & $\begin{array}{r}\text { logit } \\
\text { sd }\end{array}$ \\
\hline Incumbent Party & $\begin{array}{c}0.58^{* * *} \\
(0.11)\end{array}$ & $\begin{array}{c}0.58^{* * *} \\
(0.10)\end{array}$ & $\begin{array}{c}0.56^{* * *} \\
(0.10)\end{array}$ & $\begin{array}{c}0.55^{* * *} \\
(0.11)\end{array}$ & \\
\hline Largest Party & $\begin{array}{c}6.43^{* * *} \\
(1.09)\end{array}$ & $\begin{array}{c}2.77^{* * *} \\
(0.54)\end{array}$ & $\begin{array}{c}2.74^{* * *} \\
(0.53)\end{array}$ & $\begin{array}{c}2.79^{* * *} \\
(0.59)\end{array}$ & \\
\hline Incumbent Mayor & $\begin{array}{c}0.91 \\
(0.16)\end{array}$ & $\begin{array}{l}0.51^{* * *} \\
(0.094)\end{array}$ & $\begin{array}{l}0.52^{* * *} \\
(0.096)\end{array}$ & $\begin{array}{c}0.53^{* * *} \\
(0.10)\end{array}$ & $\begin{array}{c}0.93 \\
(0.53)\end{array}$ \\
\hline Seat Share & $\begin{array}{l}1.32^{* * *} \\
(0.036)\end{array}$ & $\begin{array}{l}1.28^{* * *} \\
(0.039)\end{array}$ & $\begin{array}{l}1.29^{* * *} \\
(0.039)\end{array}$ & $\begin{array}{c}1.66^{* * *} \\
(0.14)\end{array}$ & $\begin{array}{c}1.00 \\
(0.022)\end{array}$ \\
\hline Seat Share ${ }^{2} / 100$ & $\begin{array}{l}0.77^{* * *} \\
(0.018)\end{array}$ & $\begin{array}{l}0.81^{* * *} \\
(0.020)\end{array}$ & $\begin{array}{l}0.81^{* * *} \\
(0.020)\end{array}$ & $\begin{array}{l}0.63^{* * *} \\
(0.052)\end{array}$ & $\begin{array}{l}1.08^{* * *} \\
(0.021)\end{array}$ \\
\hline Incumbent Government & & $\begin{array}{c}5.36^{* * *} \\
(0.80)\end{array}$ & $\begin{array}{c}5.31^{* * *} \\
(0.79)\end{array}$ & $\begin{array}{c}6.54^{* * *} \\
(1.51)\end{array}$ & \\
\hline Minority Government & & $\begin{array}{c}0.44^{* * *} \\
(0.13)\end{array}$ & $\begin{array}{c}0.42^{* * *} \\
(0.12)\end{array}$ & $\begin{array}{l}0.14^{* *} \\
(0.11)\end{array}$ & $\begin{array}{c}7.92 \\
(11.9)\end{array}$ \\
\hline Minimum Winning Coalition & & $\begin{array}{l}1.56^{* *} \\
(0.29)\end{array}$ & $\begin{array}{l}1.53^{* *} \\
(0.29)\end{array}$ & $\begin{array}{c}1.34 \\
(0.34)\end{array}$ & \\
\hline N. of Parties & & $\begin{array}{l}0.39^{* * *} \\
(0.047)\end{array}$ & $\begin{array}{l}0.26^{* * *} \\
(0.039)\end{array}$ & $\begin{array}{l}0.21^{* * *} \\
(0.038)\end{array}$ & $\begin{array}{c}2.81^{* * *} \\
(0.75)\end{array}$ \\
\hline Geo. Concentration (GCI) & & & $\begin{array}{c}47.6^{* * *} \\
(39.5)\end{array}$ & $\begin{array}{c}53.6^{* * *} \\
(52.6)\end{array}$ & \\
\hline $\mathrm{N}$ & 19406 & 19406 & 19391 & \multicolumn{2}{|c|}{19391} \\
\hline LOG LIKELIHOOD & -1346.1 & -1203.5 & -1190.0 & \multicolumn{2}{|c|}{-1167.4} \\
\hline No. Form. Opp. & 490 & 490 & 489 & \multicolumn{2}{|c|}{489} \\
\hline
\end{tabular}

Exponentiated coefficients; Standard errors in parentheses

${ }^{*} p<0.10,{ }^{* *} p<0.05,{ }^{* * *} p<0.01$ 
Figure 2. Coefficient Plot

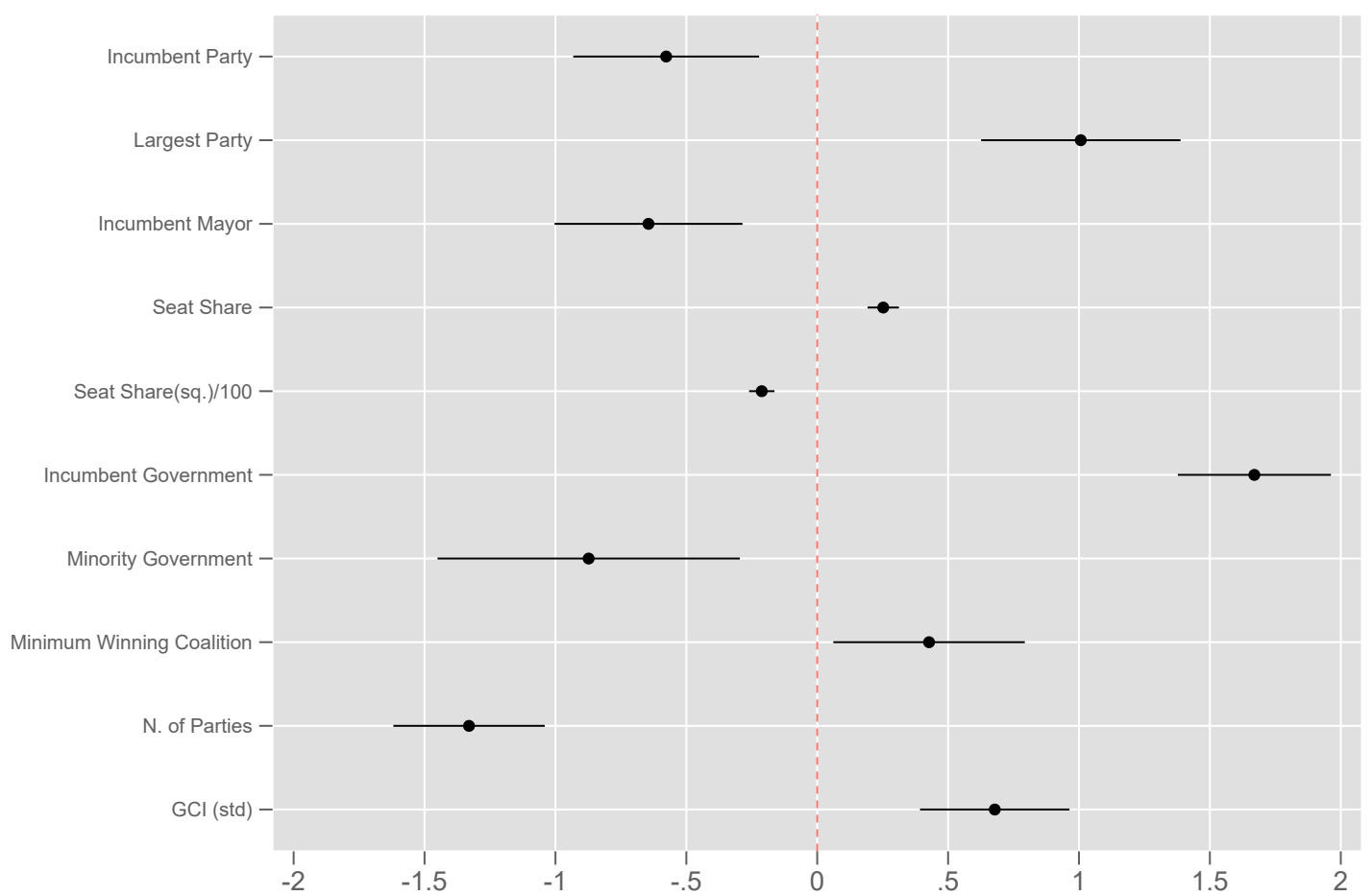

Note: Coefficient estimates from model (3) in Table 4. 95\% confidence intervals.

of a government to form, which is substantially larger than the (standardized) effect of other traditional variables, such as being the incumbent government $(+30 \%)$, having a minority status $(-35 \%)$, or being a minimum winning coalition $(+15 \%)$.

In order to interpret the substantive effect of geographical concentration at the level of individual parties instead of governments, I follow Däubler and Debus (2009) and Glasgow and Golder (2015) who generate a counterfactual comparison in one specific situation. In particular, I take the example of Torroella de Montgrí 2011 presented above, and compare parties' likelihood to join government under the real (baseline) situation and under a hypothetical case in which LEST (the party whose votes were extremely concentrated in the Eastern part of the municipality) was as homogeneously distributed across the territory as PSC (the similarly-sized party with a much more balanced distribution of voters). To do that, I calculate the probability that each party in that formation opportunity would join the government under the real-world values (baseline scenario) and under a counterfactual scenario in which the GCI of LEST scored 0.114 instead of the real $0.428 .^{13}$

\footnotetext{
${ }^{13}$ For the specific calculation of the party-level probabilities, see Glasgow and Golder $(2015,751)$.
} 
Figure 3. Substantive Effect of Geographical Concentration: Counterfactual Comparison

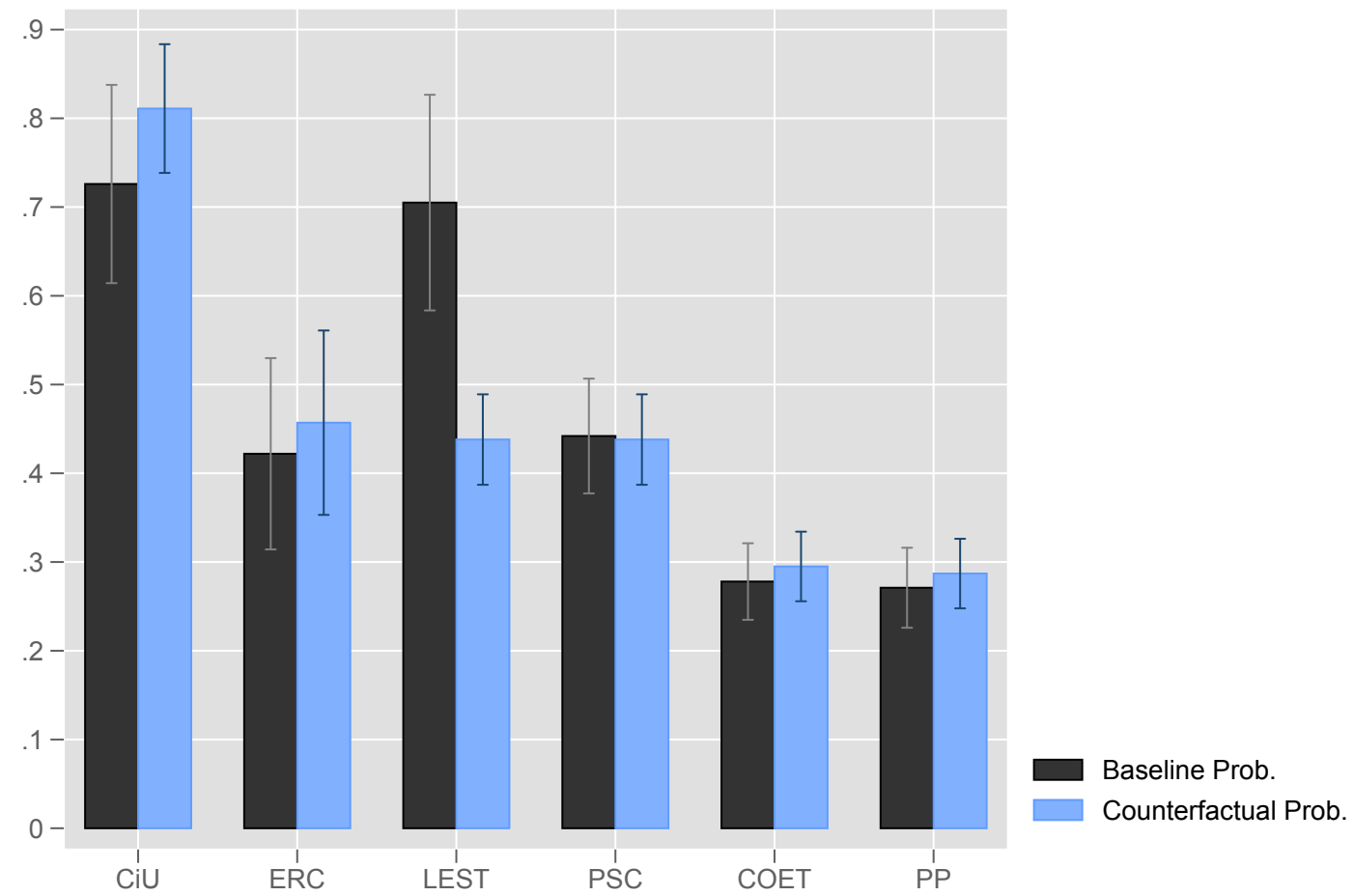

Note: Baseline scenario refers to the probabilities estimated taking the real-world values of the 2011 election in Torroella de Montgrí. Counterfactual scenario refers to a hypothetical situation in which LEST had the same GCI as PSC: 0.114 instead of 0.428. Simulations based on model (4) in Table 4. 95\% confidence intervals. 
Figure 3 shows that, while the odds of participating in government increase only slightly for the rest of the parties, the change is dramatic for LEST. The probability of joining government for this party is about $70 \%$ in the baseline scenario but plunges to around $43 \%$ in the case where their votes were more evenly spread across the municipality. Not surprisingly, the latter is precisely the participation probability for PSC, the party that was very similar to LEST except for the territorial distribution of its votes.

\section{The Location of Concentration}

Another matter of interest may be the specific location of parties' electoral strongholds and how that may impact on the government formation process. At the same level of geographical concentration, voters from certain parties may group around the hub of the municipality while other parties may have their strongholds in the periphery. Importantly, voters in the center might benefit from spending oriented to universalistic policies that are nevertheless (inadvertently or not) geographically-tailored in practice. Various social services, for instance, may be provided in (the vicinity of) the town hall premises, decreasing the cost of consumption for citizens living nearby. Similarly, as a by-product of the location of town halls, certain universalistic services may go hand-in-hand with pork-barrel spending to assist in their provision (refurbishment of streets to facilitate access to official buildings, etc.). Voters in the periphery, by contrast, are less likely to benefit from, or will face higher costs to access, these kinds of policy initiatives and may therefore demand pure pork in return.

The extent to which the specific locus of their support may or may not facilitate transactions between parties in the context of government formation bargaining is a matter for debate. On the one hand, parties defending the interests of voters in the peripheries might make the sort of demands of pork-barrel spending that are easier to accommodate through logrolling. But on the other hand, parties with strongholds around the municipality's center, may find a wider range of policies attractive from the point of view of their territorially-concentrated voters, and hence be more flexible in their demands. At any rate, this falls to be adjudicated empirically, which will help identify the scope conditions of the argument presented in the paper.

To do this, I calculated the Euclidean distance from the centroid of each census tract to the specific location of the headquarters of the municipality (typically, the town hall). I then 
divided that distance by the average tract-capital distance in that municipality to provide a relative measure (ratio) of peripherality of each census tract within a municipality. Next, I calculated a ratio of the vote share of each party in each census tract to the aggregate vote share of that party in the municipality. Then, I multiplied both ratios and averaged those products across all census tracts to end up with a single, party-dependent score of Peripherality within each municipality. Low (high) values indicate that the vote shares of the party are concentrated around the center (peripheries) of the municipality. The formula is the following:

$$
\text { Peripherality }_{j}=\frac{\sum_{i=1}^{U}\left(\frac{d_{i}}{\bar{d}} \cdot \frac{s_{j i}}{s_{j}}\right)}{U}
$$

where $d_{i}$ refers to the euclidean distance from the centroid of the territorial unit $i$ to the center of a polity with a total of $U$ units, $\bar{d}$ is the average distance between territorial units and the center in the polity, $s_{j i}$ refers to the seat share of party $j$ in unit $i$, and $s_{j}$ to the aggregate vote share of party $j$ in the polity.

\section{Table 5. Coalition Formation \& Geographical Concentration IMPACT OF PERIPHERALITY (2003-2011)}

\begin{tabular}{lcc}
\hline & $\begin{array}{c}\text { clogit } \\
(1)\end{array}$ & $\begin{array}{c}\text { clogit } \\
(2)\end{array}$ \\
\hline Geo. Concentration (GCI) & $131.4^{* * *}$ & 2.14 \\
& $(160.4)$ & $(4.59)$ \\
Peripherality & 0.54 & $0.41^{* *}$ \\
& $(0.22)$ & $(0.17)$ \\
GCI * Peripherality & & $2.71^{* *}$ \\
& & $(1.12)$ \\
Party-level Controls & YES & YES \\
Government-level Controls & YES & YES \\
\hline N & 14145 & 14145 \\
LoG LIKELIHOOD & -737.8 & -735.3 \\
No. Form. OpP. & 295 & 295 \\
\hline
\end{tabular}

Note: Exponentiated coefficients; Standard errors in parentheses.

Party-level controls include Incumbent Party, Largest Party,

Incumbent Mayor Seat Share, and Seat Share ${ }^{2} / 100$.

Government-level controls include Incumbent Government, Minority

Government, Minimum Winning Coalition, and N. of Parties. For

the complete list of coefficient estimates and standard errors see

Table B.1 in the appendix.

${ }^{*} p<0.10,{ }^{* *} p<0.05,{ }^{* * *} p<0.01$ 
Figure 4. Marginal Effects of Geo. Concentration on Formation

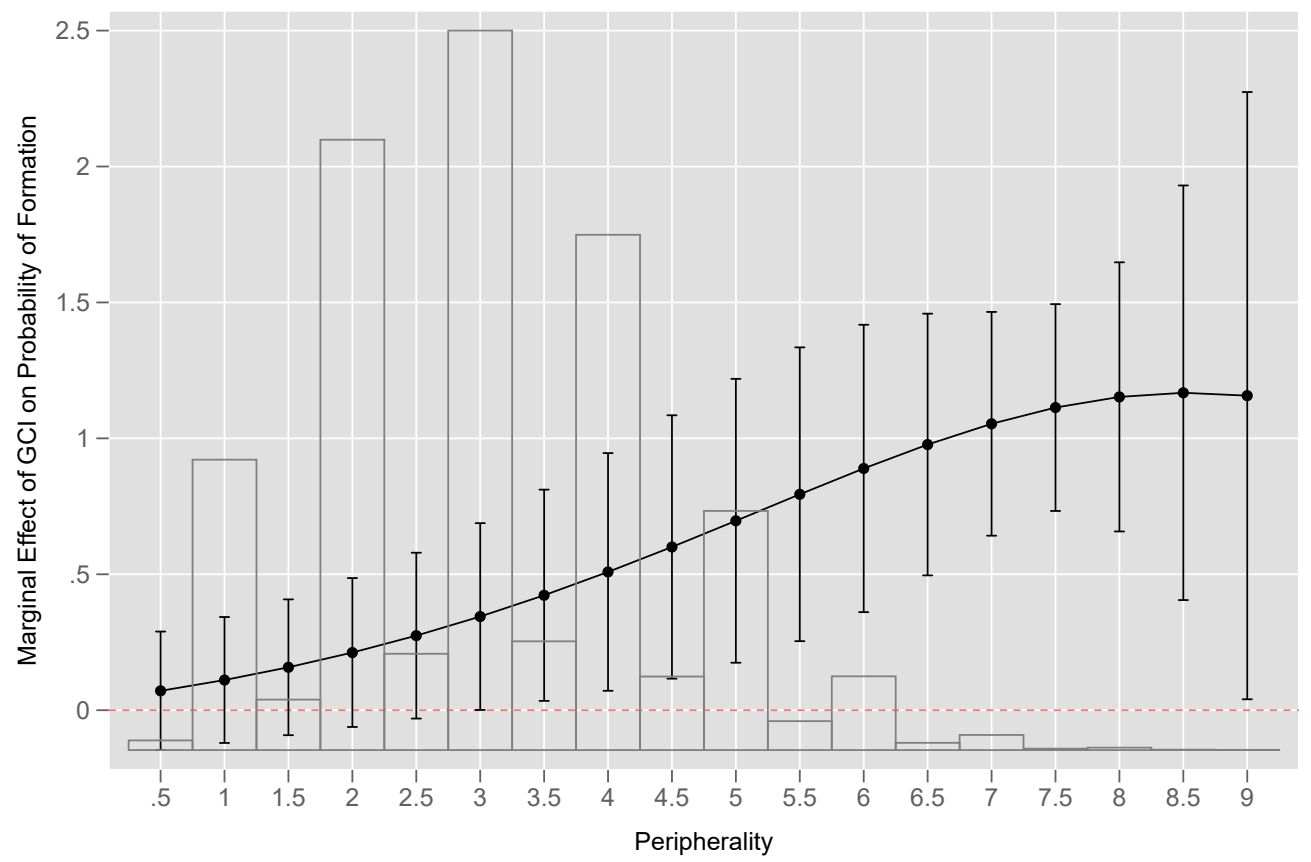

Note: $95 \%$ confidence intervals.

Table 5 presents the results of the interaction between the geographical concentration and peripherality measures. The reduction of the sample to the period 2003-2011 is due to the fact that the geographical coordinates of both census tracts and town halls in Catalonia is only available from 2002. ${ }^{14}$ Controlling for geographical concentration, interestingly, peripherality does not seem to impact on the chances of government participation (model 1). However, the influence of this variable seems to emerge conditionally. Peripherality moderates the effect of concentration on the likelihood of joining a government. More specifically, the more peripheral the location of the electoral supports of the party, the larger the impact of concentration. Or the other way around: the greater the concentration in the center, the weaker the relationship between concentration and government participation.

This can also be seen in Figure 4, which shows that the marginal effect of GCI, although always positive, only becomes significant once a minimum level of peripherality is reached (around 3 in a scale from 0 to 9 ). That means that the effect of geographical concentration is not distinguishable from zero when that concentration occurs around the center of the municipality. However, the effect is shown to be positive and significant for more than half of the sample.

\footnotetext{
${ }^{14}$ Data from the Institut Cartogràfic i Geològic de Catalunya: http://www.icgc.cat/en/
} 
This evidence sheds light on the sources of demand-satisfaction in negotiation processes for the formation of a government. The demands made by parties defending the interests of the periphery seem to be accommodated with greater alacrity than those from parties representing the interests of the center. For the latter, it appears, it is not so clear whether, or how, the 'bringing-home-the-bacon' motif works.

\subsection{Robustness tests}

The evidence presented so far seems to suggest that there is a strong positive relationship between the territorial concentration of a party's votes and its chances of joining government. However, one might think of alternative explanations for this finding. Potential confounders may include alternative sources of bargaining leverage. Parties with clearly defined strongholds may well tend to be independent organizations specific to each municipality, created to defend the interests of particular neighborhoods. These parties are typically autonomous and therefore, unconstrained by the directives imposed by regional or national party caucuses, which, for various reasons, may affect parties' ability to reach coalition compromises and join government. Models 2-6 in Table 6 control for this possibility: Independent Party is a dummy variable that indicates whether or not the party has an explicit link to a supra-municipal partisan organization that runs in the regional and/or national elections.

On the other hand, we know that a key determinant that has been unambiguously found to affect government formation is the ideological positioning of parties. In the above analyses, however, ideology has not been accounted for. The reason is simple: for many parties in the local arena, their specific goals and demands cannot be classified according to a left-right scale. However, insofar as ideological positioning and the territorial distribution of votes covary, we face an identification problem. Parties with specific territorial strongholds within a municipality, for instance, may have moderate ideological positions in the traditional dimensions of political competition and that would facilitate their participation in government. Models 3-6 in Table 6 attempt to account for the influence of ideology in the two main dimensions of the Catalan political space: left-right, and Spanish-Catalan nationalism. Inescapably, though, this effort requires the rather bold assumptions that i) all local parties with an explicit link to a specific region- or nation-wide party share the exact same position in both scales and, most heroically, 
ii) that all independent parties are placed in the middle of both dimensions (a 5 in a 0 to 10 scale)..$^{15}$

\section{Table 6. Coalition Formation \& Geographical Concentration Robustness to Ideological Distance and Type of Party}

\begin{tabular}{|c|c|c|c|c|c|c|}
\hline & $\begin{array}{c}\text { clogit } \\
\text { (1) }\end{array}$ & $\begin{array}{c}\text { clogit } \\
(2)\end{array}$ & $\begin{array}{c}\text { clogit } \\
\text { (3) }\end{array}$ & $\begin{array}{c}\text { clogit } \\
(4)\end{array}$ & $\begin{array}{c}\text { clogit } \\
(5)\end{array}$ & $\begin{array}{c}\text { clogit } \\
(6)\end{array}$ \\
\hline Geo. Concentration (GCI) & $\begin{array}{c}47.6^{* * *} \\
(39.5)\end{array}$ & $\begin{array}{c}50.7^{* * *} \\
(42.9)\end{array}$ & $\begin{array}{c}44.5^{* * *} \\
(37.9)\end{array}$ & $\begin{array}{c}27.0^{* * *} \\
(22.8)\end{array}$ & $\begin{array}{c}13.1^{* * *} \\
(11.0)\end{array}$ & $\begin{array}{c}13.5^{* * *} \\
(11.4)\end{array}$ \\
\hline Independent Party & & $\begin{array}{c}0.94 \\
(0.16)\end{array}$ & $\begin{array}{l}0.63^{* *} \\
(0.12)\end{array}$ & $\begin{array}{c}0.56^{* * *} \\
(0.11)\end{array}$ & $\begin{array}{l}0.38^{* * *} \\
(0.074)\end{array}$ & $\begin{array}{l}0.37^{* * *} \\
(0.075)\end{array}$ \\
\hline Median Party (l-r) & & & $\begin{array}{c}2.16^{* * *} \\
(0.29)\end{array}$ & & & $\begin{array}{l}0.60^{* *} \\
(0.13)\end{array}$ \\
\hline Median Party (nat) & & & $\begin{array}{c}1.45^{* * *} \\
(0.18)\end{array}$ & & & $\begin{array}{l}1.45^{* *} \\
(0.25)\end{array}$ \\
\hline Wtd Dist. to Median (l-r) & & & & $\begin{array}{l}0.35^{* * *} \\
(0.039)\end{array}$ & & $\begin{array}{l}0.43^{* * *} \\
(0.077)\end{array}$ \\
\hline Wtd Dist. to Median (nat) & & & & $\begin{array}{l}0.72^{* * *} \\
(0.067)\end{array}$ & & $\begin{array}{l}1.00 \\
(0.12)\end{array}$ \\
\hline Ideol. Range (l-r) & & & & & $\begin{array}{l}0.53^{* * *} \\
(0.028)\end{array}$ & $\begin{array}{l}0.61^{* * *} \\
(0.037)\end{array}$ \\
\hline Ideol. Range (nat) & & & & & $\begin{array}{l}0.83^{* * *} \\
(0.036)\end{array}$ & $\begin{array}{c}0.87^{* * *} \\
(0.042)\end{array}$ \\
\hline Party-level Controls & YES & YES & YES & YES & YES & YES \\
\hline Government-level Controls & YES & YES & YES & YES & YES & YES \\
\hline $\begin{array}{l}\text { N } \\
\text { LOG LIKELIHOOD } \\
\text { NO. FORM. OPP. }\end{array}$ & $\begin{array}{c}19,391 \\
-1,190.0 \\
489\end{array}$ & $\begin{array}{c}19,391 \\
-1,189.9 \\
489\end{array}$ & $\begin{array}{c}19,391 \\
-1,170.5 \\
489\end{array}$ & $\begin{array}{c}19,391 \\
-1,133.3 \\
489\end{array}$ & $\begin{array}{c}19,391 \\
-1,102.5 \\
489\end{array}$ & $\begin{array}{c}19,391 \\
-1,085.9 \\
489\end{array}$ \\
\hline
\end{tabular}

The results of these robustness tests show that, before controlling for ideology, governments which include independent parties seem to be neither more nor less likely to form. Once the ideological controls are included, however, independent parties appear to be less, not more, prone to becoming a member of the invested government. ${ }^{16}$ With respect to ideology -and under the strict assumptions described above- the results again square with previous findings: being in the median of both dimensions tends to make participation in government more likely;

\footnotetext{
${ }^{15}$ Alternative measurement decisions such as considering these parties to be placed in the average position of the rest of parties in the formation opportunity in both dimensions leave results fundamentally unaltered. For parties with an explicit link to regional or nation-wide parties, on the other hand, the positions are drawn from survey data on perceived party positions from the Spanish Centre for Sociological Research (Centro de Investigaciones Sociológicas). See Table C.1 in the Appendix for further details.

${ }^{16}$ Moreover, in an interactive model adding the multiplicative term $G C I{ }^{*}$ Independent Party, the interaction is not statistically significant, indicating that the effect of the GCI is no different for independent an nonindependent parties.
} 
while ideological distance, as measured in Glasgow and Golder (2015), and the ideological range between the most extreme positions within the potential government, substantially decrease the odds of formation. But most importantly, the effect of geographical concentration remains positive and strong across the board. It is true that the magnitude of the GCI effect decreases, in particular when both ideological distance and range are controlled for, but it is always strongly statistically significant $(\mathrm{p}<.01)$.

In addition, I check for the robustness of the above findings through the consideration of alternative measures of parties' geographical concentration. Table 7 presents the results of the baseline model but with different specifications of the key independent variable. All measures are standardized to facilitate interpretation of the coefficient estimates in terms of the impact of one additional standard deviation. Column 1 basically offers the results of the baseline model (see column 3 in Table 4) but with the standardized GCI. In column 2 the GCI of the potential government is averaged across the number of participants in the government, whereas in column 3 the GCI is weighted by the seat share contribution of each party to the coalition. Columns 4 and 5 use Bochsler's (2010) 'weighted Party Nationalization Score' (wPNS), subtracted from 1; which is essentially the same measure as the GCI, but without correcting for the unequal number of census tracts across municipalities. Finally, I also use the Gini index itself in columns 6-7. ${ }^{17}$ The impact of geographical concentration seems to stand up to scrutiny under the specific measure being used, with coefficients of a larger or smaller magnitude depending on the particular specification, but in any case reaching conventional levels of statistical significance.

Lastly, as a final robustness check, I take parties rather than potential governments as the objects of observation and offer estimates of various binary logit regressions in Table 8. Columns 1 and 2 show the impact of GCI at the party level, specifying clustered standard errors and including formation opportunity fixed effects, respectively. Columns 3-5 dichotomize the GCI to build an indicator variable taking value ' 1 ' if that party has a GCI score above 0.127 (the 90th percentile of the distribution) and ' 0 ' otherwise. In addition, in order to improve balance, the coefficient for the dichotomous GCI in column 4 is estimated through the implementation of coarsened exact matching (Iacus et al., 2008) using Sturge's binning algorithm, while the model

\footnotetext{
${ }^{17}$ Starting in model 3 , the columns in odd numbers present the estimates of the different measures weighted by the seat share contribution of each party to the government.
} 


\section{Table 7. Coalition Formation \& Geographical Concentration Robustness to Alternative Measures}

\begin{tabular}{|c|c|c|c|c|c|c|c|}
\hline & $\begin{array}{l}\text { clogit } \\
(1)\end{array}$ & $\begin{array}{l}\text { clogit } \\
(2)\end{array}$ & $\begin{array}{c}\text { clogit } \\
(3)\end{array}$ & $\begin{array}{l}\text { clogit } \\
(4)\end{array}$ & $\begin{array}{c}\text { clogit } \\
(5)\end{array}$ & $\begin{array}{c}\text { clogit } \\
(6)\end{array}$ & $\begin{array}{l}\text { clogit } \\
(7)\end{array}$ \\
\hline GCI (std) & $\begin{array}{c}1.97^{* * *} \\
(0.29)\end{array}$ & & & & & & \\
\hline GCI (av.) (std) & & $\begin{array}{c}1.34^{* * *} \\
(0.14)\end{array}$ & & & & & \\
\hline GCI (wtd contrib.) (std) & & & $\begin{array}{c}1.48^{* * *} \\
(0.18)\end{array}$ & & & & \\
\hline Rev. wPNS (std) & & & & $\begin{array}{c}1.58^{* * *} \\
(0.24)\end{array}$ & & & \\
\hline Rev. wPNS (wtd contrib.) (std) & & & & & $\begin{array}{l}1.37^{* *} \\
(0.19)\end{array}$ & & \\
\hline Gini (std) & & & & & & $\begin{array}{c}1.60^{* * *} \\
(0.25)\end{array}$ & \\
\hline Gini (wtd contrib.) (std) & & & & & & & $\begin{array}{l}1.35^{* *} \\
(0.19)\end{array}$ \\
\hline Party-level Controls & YES & YES & YES & YES & YES & YES & YES \\
\hline Government-level Controls & YES & YES & YES & YES & YES & YES & YES \\
\hline $\mathrm{N}$ & 19,391 & 19,391 & 19,391 & 19,406 & 19,406 & 19,391 & 19,391 \\
\hline LOG LIKELIHOOD & -1190.0 & -1197.7 & -1197.4 & -1199.1 & -1201.1 & -1197.4 & -1199.5 \\
\hline No. Form. OpP. & 489 & 489 & 489 & 490 & 490 & 489 & 489 \\
\hline
\end{tabular}

Note: Exponentiated coefficients; Standard errors in parentheses. Party-level controls include Incumbent Party, Largest Party, Incumbent Mayor Seat Share, and Seat Share 2 /100. Government-level controls include Incumbent Government, Minority Government, Minimum Winning Coalition, and N. of Parties. For the complete list of coefficient estimates and standard errors see Table B.3 in the appendix.

${ }^{*} p<0.10,{ }^{* *} p<0.05,{ }^{* * *} p<0.01$ 
in column 5 uses the same procedure but forces strata to have the same number of treated and control units. All results are reassuring in that a strong empirical relationship exists between the geographical concentration of a party's support base and its odds of being a member of the next government.

\section{Table 8. Coalition Formation \& Geographical Concentration Robustness TO BinARY LOGITS}

\begin{tabular}{lccccc}
\hline & clust s.e. & $\begin{array}{c}\text { form. opp. } \\
\text { FE }\end{array}$ & $\begin{array}{c}\text { Dichot. IV } \\
\text { CE match. }\end{array}$ & $\begin{array}{c}\text { CE match. } \\
(\mathrm{k} 2 \mathrm{k})\end{array}$ \\
& $(1)$ & $(2)$ & $(3)$ & $(4)$ & $(5)$ \\
\hline Geo. Concentration (GCI) & $18.5^{* * *}$ & $13.5^{* * *}$ & & & \\
& $(12.0)$ & $(13.6)$ & & & $1.64^{* * *}$ \\
High GCI (>p90) & & & $1.37^{* *}$ & $1.35^{* *}$ & $(0.31)$ \\
& & & $(0.20)$ & $(0.19)$ & YES \\
Party-level Controls & YES & YES & YES & YES & 480 \\
\hline N & 2445 & 2418 & 2449 & 2177 & -296.3 \\
LoG LikELIHOOD & -1457.4 & -842.5 & -1466.0 & -1216.6 & 490 \\
No. Form. OpP. & 489 & 482 & 490 & 490 \\
\hline
\end{tabular}

Exponentiated coefficients; Standard errors in parentheses. Party-level controls include Incumbent Party, Largest Party, Incumbent Mayor Seat Share, and Seat Share ${ }^{2} / 100$. For the complete list of coefficient estimates and standard errors see Table B.4 in the appendix.

${ }^{*} p<0.10,{ }^{* *} p<0.05,{ }^{* * *} p<0.01$

\section{Conclusions}

The different ways in which votes can be distributed across the territory shape many aspects of political systems. Parties whose votes are regionalized in a particular area respond to electoral incentives that are very different from those faced by parties with a more homogeneous geographical distribution of votes. This is then expressed in their own policy agenda, which they try to pursue with greater or lesser success. And while evidence has accrued to suggest that the demands of regionalized parties are sometimes more likely to be translated into actual policy than others, we know little about their participation in the governments that are ultimately in charge of making these policies.

This paper has argued that geographically concentrated parties seek policy objectives that are often orthogonal to the ones other parties pursue, and that this feature opens the door 
to policy compromises that would be unavailable if all parties were homogeneously distributed across the territory. Because they are primarily focused on the region(s) where they obtain the lion's share of their votes, rather than on the whole territory, they will tend to prioritize locally-targeted policies (mostly pork-barrel spending) over the universalistic policies defended by more programmatic parties. The presence of this type of parties in a party system, therefore, greases the mechanism whereby interparty agreements are built: it affords opportunities for mutually advantageous logrolling both with parties that pursue other types of (programmatic) objectives and with parties whose interests are similarly locally focused, but in different areas of the territory. In parliamentary systems, that should be expressed in the demands that parties bring to the table when it is time to negotiate over the formation of a new government, in the following terms: the geographical concentration of a party's votes is expected to increase its compatibility with other parties thereby making its participation in government more likely.

This expectation has been tested on a sample of around 500 formation opportunities and 20,000 potential governments in 131 municipalities from Catalonia, Spain. These provide an appropriate test bed for this general theory as their local executives have multi-purpose competences and elections commonly result in minority configurations. Using a measure based on the Gini coefficient, the paper has documented a robust and remarkably sizable positive impact of geographic concentration on the likelihood of government participation, which is actually greater than that of other, more traditionally observed variables in the study of government formation processes. Furthermore, this effect is found to be even stronger when the territorial concentration of the party is located in the periphery of the territory rather than in the center.

This result has important implications for scholarly research on government formation, party politics, and political geography. The territorial distribution of votes at the party level seems to be an equally, if not more, important determinant of 'who gets in' as compared to other, more traditional, factors and, therefore, should be taken into account in future studies on the topic. Similarly, these results may provide clues to understanding the success of regional parties under very different institutional contexts: it is through demands that are more amenable to logroll bartering that these parties are able to succeed in shaping national governments' policies. Also, this paper has demonstrated that research on political geography should consider the impact that geography exerts on phenomena that operate in between citizens' electorally-expressed 
preferences and policy outcomes, such as the selection of political executives.

At a more general level, the findings are also highly relevant for the functioning of democratic systems. By examining the process by which governments are formed, this paper has provided evidence to suggest that the political interests of territorially concentrated societal groups are more likely to be reflected in executive policies than the programmatic demands of those whose political affiliations are more evenly distributed across the geography of the system, even in proportional electoral systems. Future research should confirm whether or not this is actually the case, as implied by the theoretical argument put forward in this paper. Likewise, forthcoming works may explore potential heterogeneous effects of geographical concentration: its impact could be conditional on contextual characteristics of the polity and/or time period, that fall beyond the scope of what this paper has intended to show. Finally, the territorial distribution of the votes of a party is clearly endogenous to both observable and, perhaps more importantly, unobservable characteristics of the party. To the extent that it is also relevant to explaining participation in government, the causal nature of the relationship between geographical concentration and government formation needs to be approached with caution. Exogenous sources of variation in the territorial distribution of parties' votes should be studied before a stronger causal inference can be drawn.

\section{References}

Bäck, Hanna. 2003. "Explaining and predicting coalition outcomes: Conclusions from studying data on local coalitions." European Journal of Political Research 42(4):441-472.

Bäck, Hanna. 2008. "Intra-Party Politics and Coalition Formation Evidence from Swedish Local Government." Party Politics 14(1):71-89.

Bäck, Hanna and Patrick Dumont. 2008. "Making the first move: A two-stage analysis of the role of formateurs in parliamentary government formation." Public Choice 135(3-4):353-373.

Barberá, Pablo. 2010. "Voting for parties or for candidates? The trade-off between party and personal representation in Spanish regional and local elections." Revista Española de Investigaciones Sociológicas 132:35-63. 
Blockmans, Tom, Benny Geys, Bruno Heyndels and Bram Mahieu. 2016. "Bargaining complexity and the duration of government formation: Evidence from Flemish municipalities." Public Choice 167(1):131-143.

Bochsler, Daniel. 2010. "Measuring party nationalisation: A new Gini-based indicator that corrects for the number of units." Electoral Studies 29(1):155-168.

Cheibub, José Antonio and Adam Przeworski. 1999. Democracy, elections, and accountability for economic outcomes. In Democracy, accountability, and representation, ed. Adam Przeworski, Susan Stokes and Bernard Manin. New York: Cambridge University Press pp. 222250.

Christiansen, Nels, Sotiris Georganas and John H. Kagel. 2014. "Coalition formation in a legislative voting game." American Economic Journal: Microeconomics 6(1):182-204.

Daniele, Gianmarco, Sergio Galletta and Benny Geys. 2017. "Abandon ship? Party brands and politicians' responses to a political scandal." IdEP Economic Papers 2017/03.

Däubler, Thomas and Marc Debus. 2009. "Government formation and policy formulation in the German states." Regional $\&$ Federal Studies 19(1):73-95.

De Winter, Lieven and Huri Tursan. 1998. Regionalist parties in western Europe. London: Routledge.

Debus, Marc and Martin Gross. 2016. "Coalition formation at the local level." Party Politics $22(6): 835-846$.

Diermeier, Daniel and Antonio Merlo. 2004. "An Empirical Investigation of Coalition Bargaining Procedures." Journal of Public Economics 88(3):783-797.

Druckman, James N. and Andrew Roberts. 2007. "Communist successor parties and coalition formation in Eastern Europe." Legislative Studies Quarterly 32(1):5-31.

Druckman, James N., Lanny W. Martin and Michael F. Thies. 2005. "Influence without confidence: Upper chambers and government formation." Legislative Studies Quarterly 30(4):529548. 
Ellwood, John W. and Eric M. Patashnik. 1993. "In praise of pork." Public Interest (110):19-33.

Evans, Diana. 1994. "Policy and pork: the use of pork barrel projects to build policy coalitions in the House of Representatives." American Journal of Political Science pp. 894-917.

Evans, Diana. 2004. Greasing the wheels: Using pork barrel projects to build majority coalitions in Congress. Cambridge: Cambridge University Press.

Falcó-Gimeno, Albert. 2014. "The use of control mechanisms in coalition governments: The role of preference tangentiality and repeated interactions." Party Politics 20(3):341-356.

Ferejohn, John A. 1974. Pork Barrel Politics: Rivers and Harbors Legislation, 1947-1968. Stanford, CA: Standford University Press.

Fujiwara, Thomas and Carlos Sanz. 2017. "Norms in bargaining: Evidence from government formation in Spain." Manuscript. Princeton University.

Glasgow, Garrett, Matt Golder and Sona N. Golder. 2012. "New empirical strategies for the study of parliamentary government formation." Political Analysis 20(2):248-270.

Glasgow, Garrett and Sona N. Golder. 2015. "A New Approach to the Study of Parties Entering Government." British Journal of Political Science 45(4):739-754.

Golder, Sona N. 2006. The logic of pre-electoral coalition formation. Ohio State University Press.

Heller, William B. 2002. "Regional Parties and National Politics in Europe Spain's Estado De Las Autonomías, 1993 to 2000." Comparative Political Studies 35(6):657-685.

Iacus, Stefano Maria, Gary King and Giuseppe Porro. 2008. "Matching for causal inference without balance checking." Available at SSRN: https://ssrn.com/abstract=1152391.

Indridason, Indridi H. 2008. "Does terrorism influence domestic politics? Coalition formation and terrorist incidents." Journal of Peace Research 45(2):241-259.

Indridason, Indridi H. 2011. "Coalition Formation and Polarisation." European Journal of Political Research 50(5):689-718. 
Isaksson, Guy-Erik. 2005. "From election to government: Principal rules and deviant cases." Government and Opposition 40(3):329-357.

Jones, Mark P. and Scott Mainwaring. 2003. "The nationalization of parties and party systems an empirical measure and an application to the Americas." Party Politics 9(2):139-166.

Jurado, Ignacio. 2014. "Party system nationalisation and social spending." European Journal of Political Research 53(2):288-307.

Jurado, Ignacio and Sandra León. 2016. "Geography Matters: The Conditional Effect of Electoral Systems on Social Spending." British Journal of Political Science forthcoming.

Jusko, Karen L. 2015. "Electoral geography and redistributive politics." Journal of Theoretical Politics 27(2):269-287.

Kang, Shin-Goo. 2009. "The influence of presidential heads of state on government formation in European democracies: Empirical evidence." European Journal of Political Research 48(4):543-572.

Kellam, Marisa. 2015. "Parties for hire. How particularistic parties influence presidents? governing strategies." Party Politics 21(4):515-526.

Kitschelt, Herbert. 2000. "Linkages between citizens and politicians in democratic polities." Comparative political studies 33(6-7):845-879.

Laver, Michael, Colin Rallings and Michael Thrasher. 1987. "Coalition theory and local government: Coalition payoffs in Britain." British Journal of Political Science 17(4):501-509.

Luebbert, Gregory M. 1986. Comparative democracy: Policymaking and governing coalitions in Europe and Israel. New York, NY: Columbia University Press.

Maravall, José M. 2007. Accountability and the Survival of Governments. In The Oxford Handbook of Comparative Politics, ed. Carles Boix and Susan Stokes. Oxford: Oxford University Press pp. 910-939.

Maravall, José M. 2010. “Accountability in coalition governments." Annual Review of Political Science 13:81-100. 
Martin, Lanny W. and Randolph T. Stevenson. 2001. "Government formation in parliamentary democracies." American Journal of Political Science 45(1):33-50.

Martin, Lanny W. and Randolph T. Stevenson. 2010. "The conditional impact of incumbency on government formation." American Political Science Review 104(3):503-518.

Martínez Farrero, Santi. 2015. Coalition Politics in Catalan Local Governments, 1979-2011 PhD thesis Universitat de Barcelona. http://hdl.handle.net/10803/286733.

Mattila, Mikko and Tapio Raunio. 2004. "Does winning pay? Electoral success and government formation in 15 West European countries." European Journal of Political Research 43(2):263285.

Mayhew, David R. 1974. Congress: The electoral connection. New Haven: Yale University Press.

McFadden, Daniel and Kenneth Train. 2000. "Mixed MNL models for discrete response." Journal of Applied Econometrics 15(5):447-470.

McGillivray, Fiona. 2004. Privileging industry: The comparative politics of trade and industrial policy. Princeton: Princeton University Press.

Rickard, Stephanie J. 2012. "Electoral systems, voters' interests and geographic dispersion." British Journal of Political Science 42(4):855-877.

Riera, Pedro, Raúl Gómez, Juan Antonio Mayoral, Pablo Barberá and José Ramón Montero. 2017. "Elecciones municipales en España. La personalización del voto." Revista Internacional de Sociología 75(2):1-18.

Riera, Pedro, Raúl Gómez, Pablo Barberá, Juan Antonio Mayoral and José Ramón Montero. 2016. "Elecciones municipales en España: un análisis multinivel de los determinantes individuales y contextuales del voto." Revista de Estudios Políticos 172:47-82.

Rodden, Jonathan. 2010. "The geographic distribution of political preferences." Annual Review of Political Science 13:321-340.

Savage, Lee Michael. 2014. "Who gets in? Ideology and government membership in Central and Eastern Europe." Party Politics 20(4):547-562. 
Serritzlew, Søren, Jens Blom-hansen and Asbjørn Skjæveland. 2010. "Portfolio Allocation or Policy Horizons? Determinants of Coalition Formation in Danish Local Government." Local Government Studies 36(6):843-866.

Skjaeveland, Asbjørn, Søren Serritzlew and Jens Blom-hansen. 2007. "Theories of coalition formation: An empirical test using data from Danish local government." European Journal of Political Research 46(5):721-745.

Skrinis, Stavros and Eftichia Teperoglou. 2008. Studying and comparing second-order elections. Examples from Greece, Portugal and Spain. In The multilevel electoral system of the EU, Connex Report series, ed. Cees van der Eijk and Hermann Schmitt. Vol. 4 of CONNEX Report Series Mannheim: University of Mannheim pp. 163-89.

Solé-Ollé, Albert. 2006. "The effects of party competition on budget outcomes: Empirical evidence from local governments in Spain." Public Choice 126(1-2):145-176.

Steunenberg, Bernard. 1992. "Coalition theories: Empirical evidence for Dutch municipalities." European Journal of Political Research 22(3):245-278.

Tavits, Margit. 2008. "The Role of Parties' Past Behavior in Coalition Formation." American Political Science Review 102(4):495-507.

Villata Puig, Gonzalo. 2013. Spain - Ungovernable Spain: Regional subsidiarity and the crisis of local governance. In Local government in Europe: The 'Fourth Level' in the EU multi-layered system of governance, ed. Carlo Panara and Michael R. Varney. Routledge pp. 277-304.

Warwick, Paul V. 1996. "Coalition government membership in West European parliamentary democracies." British Journal of Political Science 26(4):471-499.

Warwick, Paul V. 2005. "Do policy horizons structure the formation of parliamentary governments? The evidence from an expert survey." American Journal of Political Science 49(2):373-387. 


\section{Appendices}

A Variance of GCIs $\quad 2$

B Complete Regression Tables $\quad 4$

B.1 The Impact of Peripherality . . . . . . . . . . . . . . . . . 4

B.2 Addition of Ideological Covariates . . . . . . . . . . . . . . . . . . . 5

B.3 Alternative Measures of Geographical Concentration _ . . . . . . . . . . . 6

B.4 Binary Logit Models . . . . . . . . . . . . . . . . . . . . . 8

$\begin{array}{lr}\text { C Party Positions } & 9\end{array}$ 


\section{A Variance of GCIs}

The main text posed a conjecture about whether it may not be only the overall geographical concentration of a coalition that mattered for the likelihood of formation, but also the disparity between parties. Table A.1 provides the estimates of two additive and two interactive conditional logit models (based on model 3 in Table 4), that include the standard deviation of parties' Geographical Concentration Index (SD of GCI) as a covariate, and its interaction with the overall GCI. The difference between the columns 1 and 2 on the one hand, and columns 3 and 4 on the other, is that for the former, those potential governments composed of one party only are assigned a zero standard deviation of geographical concentration, while for the latter, the measure is set to a missing value. The discrepancy in the number of observations is in line with this decision. All in all, neither the main effects nor the interactions yield any statis-

tically or substantially significant effect, suggesting that the variance of parties' geographical concentration does not affect government formation once we control for the coalition's GCI itself. 
Table A.1. Coalition Formation \& Geographical Concentration INCLUDING VARIANCE OF GCIS

\begin{tabular}{|c|c|c|c|c|}
\hline & $\begin{array}{l}\text { clogit } \\
\text { (1) }\end{array}$ & $\begin{array}{c}\text { clogit } \\
(2)\end{array}$ & $\begin{array}{c}\text { clogit } \\
(3)\end{array}$ & $\begin{array}{c}\text { clogit } \\
(4)\end{array}$ \\
\hline Incumbent Party & $\begin{array}{c}0.56^{* * *} \\
(0.10)\end{array}$ & $\begin{array}{c}0.56^{* * *} \\
(0.10)\end{array}$ & $\begin{array}{c}0.51^{* * *} \\
(0.10)\end{array}$ & $\begin{array}{c}0.51^{* * *} \\
(0.11)\end{array}$ \\
\hline Largest Party & $\begin{array}{c}2.77^{* * *} \\
(0.54)\end{array}$ & $\begin{array}{c}2.77^{* * *} \\
(0.54)\end{array}$ & $\begin{array}{c}2.38^{* * *} \\
(0.50)\end{array}$ & $\begin{array}{c}2.37^{* * *} \\
(0.50)\end{array}$ \\
\hline Incumbent Mayor & $\begin{array}{c}0.53^{* * *} \\
(0.096)\end{array}$ & $\begin{array}{l}0.53^{* * *} \\
(0.096)\end{array}$ & $\begin{array}{c}0.54^{* * *} \\
(0.10)\end{array}$ & $\begin{array}{c}0.53^{* * *} \\
(0.10)\end{array}$ \\
\hline Seat Share & $\begin{array}{l}1.29^{* * *} \\
(0.039)\end{array}$ & $\begin{array}{l}1.29^{* * *} \\
(0.039)\end{array}$ & $\begin{array}{l}1.22^{* * *} \\
(0.053)\end{array}$ & $\begin{array}{l}1.22^{* * *} \\
(0.053)\end{array}$ \\
\hline Seat Share ${ }^{2} / 100$ & $\begin{array}{l}0.81^{* * *} \\
(0.020)\end{array}$ & $\begin{array}{l}0.81^{* * *} \\
(0.020)\end{array}$ & $\begin{array}{l}0.84^{* * *} \\
(0.028)\end{array}$ & $\begin{array}{l}0.84^{* * *} \\
(0.028)\end{array}$ \\
\hline Incumbent Government & $\begin{array}{c}5.27^{* * *} \\
(0.79)\end{array}$ & $\begin{array}{c}5.25^{* * *} \\
(0.78)\end{array}$ & $\begin{array}{c}7.47^{* * *} \\
(1.51)\end{array}$ & $\begin{array}{c}7.50^{* * *} \\
(1.52)\end{array}$ \\
\hline Minority Government & $\begin{array}{c}0.41^{* * *} \\
(0.12)\end{array}$ & $\begin{array}{c}0.41^{* * *} \\
(0.12)\end{array}$ & $\begin{array}{l}0.26^{* * *} \\
(0.097)\end{array}$ & $\begin{array}{l}0.26^{* * *} \\
(0.097)\end{array}$ \\
\hline Minimum Winning Coalition & $\begin{array}{l}1.56^{* *} \\
(0.29)\end{array}$ & $\begin{array}{l}1.57^{* *} \\
(0.29)\end{array}$ & $\begin{array}{c}2.01^{* * *} \\
(0.41)\end{array}$ & $\begin{array}{c}2.02^{* * *} \\
(0.41)\end{array}$ \\
\hline N. of Parties & $\begin{array}{c}0.25^{* * *} \\
(0.038)\end{array}$ & $\begin{array}{c}0.26^{* * *} \\
(0.043)\end{array}$ & $\begin{array}{l}0.41^{* * *} \\
(0.072)\end{array}$ & $\begin{array}{l}0.40^{* * *} \\
(0.074)\end{array}$ \\
\hline GCI & $\begin{array}{c}108.6^{* * *} \\
(113.2)\end{array}$ & $\begin{array}{l}75.8^{* * *} \\
(100.0)\end{array}$ & $\begin{array}{l}17.0^{* *} \\
(19.3)\end{array}$ & $\begin{array}{l}25.3^{* *} \\
(36.8)\end{array}$ \\
\hline $\mathrm{SD}$ of GCI & $\begin{array}{l}0.058 \\
(0.13)\end{array}$ & $\begin{array}{c}0.019 \\
(0.064)\end{array}$ & $\begin{array}{l}1.29 \\
(3.35)\end{array}$ & $\begin{array}{c}5.48 \\
(23.1)\end{array}$ \\
\hline $\mathrm{GCI} * \mathrm{SD}$ of $\mathrm{GCI}$ & & $\begin{array}{c}17.4 \\
(111.7)\end{array}$ & & $\begin{array}{l}0.042 \\
(0.31)\end{array}$ \\
\hline $\begin{array}{l}\text { N } \\
\text { LOG LIKELIHOOD } \\
\text { NO. FORM. OPP. }\end{array}$ & $\begin{array}{c}19,391 \\
-1189.2 \\
489\end{array}$ & $\begin{array}{c}19,391 \\
-1189.1 \\
489\end{array}$ & $\begin{array}{l}13,947 \\
-887.8 \\
382\end{array}$ & $\begin{array}{c}13,947 \\
-887.7 \\
382\end{array}$ \\
\hline
\end{tabular}




\section{B Complete Regression Tables}

\section{B.1 The Impact of Peripherality}

This appendix offers the estimates of the full specifications of the models summarized in Table 5 , including the covariates not shown in the main text.

Table B.1. Coalition Formation \& Geographical Concentration ImpaCt of Peripherality (2003-2011)

\begin{tabular}{|c|c|c|}
\hline & $\begin{array}{l}\text { clogit } \\
(1)\end{array}$ & $\begin{array}{c}\text { clogit } \\
(2)\end{array}$ \\
\hline Incumbent Party & $\begin{array}{c}0.56^{* * *} \\
(0.12)\end{array}$ & $\begin{array}{c}0.56^{* * *} \\
(0.12)\end{array}$ \\
\hline Largest Party & $\begin{array}{c}2.31^{* * *} \\
(0.56)\end{array}$ & $\begin{array}{c}2.26^{* * *} \\
(0.55)\end{array}$ \\
\hline Incumbent Mayor & $\begin{array}{c}0.50^{* * *} \\
(0.11)\end{array}$ & $\begin{array}{c}0.51^{* * *} \\
(0.11)\end{array}$ \\
\hline Seat Share & $\begin{array}{l}1.38^{* * *} \\
(0.064)\end{array}$ & $\begin{array}{l}1.39^{* * *} \\
(0.065)\end{array}$ \\
\hline Seat Share ${ }^{2} / 100$ & $\begin{array}{l}0.75^{* * *} \\
(0.030)\end{array}$ & $\begin{array}{l}0.74^{* * *} \\
(0.030)\end{array}$ \\
\hline Incumbent Government & $\begin{array}{c}4.42^{* * *} \\
(0.87)\end{array}$ & $\begin{array}{c}4.31^{* * *} \\
(0.85)\end{array}$ \\
\hline Minority Government & $\begin{array}{l}0.22^{* * *} \\
(0.082)\end{array}$ & $\begin{array}{l}0.20^{* * *} \\
(0.079)\end{array}$ \\
\hline Minimum Winning Coalition & $\begin{array}{c}1.06 \\
(0.25)\end{array}$ & $\begin{array}{c}1.08 \\
(0.26)\end{array}$ \\
\hline N. of Parties & $\begin{array}{c}0.36^{* * *} \\
(0.14)\end{array}$ & $\begin{array}{l}0.44^{* *} \\
(0.18)\end{array}$ \\
\hline Geo. Concentration (GCI) & $\begin{array}{c}131.4^{* * *} \\
(160.4)\end{array}$ & $\begin{array}{c}2.14 \\
(4.59)\end{array}$ \\
\hline Peripherality & $\begin{array}{c}0.54 \\
(0.22)\end{array}$ & $\begin{array}{l}0.41^{* *} \\
(0.17)\end{array}$ \\
\hline GCI $*$ Peripherality & & $\begin{array}{l}2.71^{* *} \\
(1.12)\end{array}$ \\
\hline $\mathrm{N}$ & 14145 & 14145 \\
\hline LOG LIKELIHOOD & -737.8 & -735.3 \\
\hline No. Form. OpP. & 295 & 295 \\
\hline
\end{tabular}




\section{B.2 Addition of Ideological Covariates}

This appendix offers the estimates of the full specifications of the models summarized in Table 6 , including the covariates not shown in the main text.

Table B.2. Coalition Formation \& Geographical Concentration Robustness to Ideological Distance and Type of Party

\begin{tabular}{|c|c|c|c|c|c|c|}
\hline & $\begin{array}{c}\text { clogit } \\
(1)\end{array}$ & $\begin{array}{c}\text { clogit } \\
(2)\end{array}$ & $\begin{array}{c}\text { clogit } \\
(3)\end{array}$ & $\begin{array}{c}\text { clogit } \\
(4)\end{array}$ & $\begin{array}{c}\text { clogit } \\
(5)\end{array}$ & $\begin{array}{c}\text { clogit } \\
(6)\end{array}$ \\
\hline Incumbent Party & $\begin{array}{c}0.56^{* * *} \\
(0.10)\end{array}$ & $\begin{array}{c}0.56^{* * *} \\
(0.10)\end{array}$ & $\begin{array}{c}0.56^{* * *} \\
(0.10)\end{array}$ & $\begin{array}{c}0.55^{* * *} \\
(0.10)\end{array}$ & $\begin{array}{c}0.61^{* * *} \\
(0.11)\end{array}$ & $\begin{array}{c}0.58^{* * *} \\
(0.11)\end{array}$ \\
\hline Largest Party & $\begin{array}{c}2.74^{* * *} \\
(0.53)\end{array}$ & $\begin{array}{c}2.74^{* * *} \\
(0.53)\end{array}$ & $\begin{array}{c}2.29^{* * *} \\
(0.46)\end{array}$ & $\begin{array}{c}1.82^{* * *} \\
(0.39)\end{array}$ & $\begin{array}{c}2.78^{* * *} \\
(0.55)\end{array}$ & $\begin{array}{c}2.15^{* * *} \\
(0.46)\end{array}$ \\
\hline Incumbent Mayor & $\begin{array}{l}0.52^{* * *} \\
(0.096)\end{array}$ & $\begin{array}{l}0.53^{* * *} \\
(0.096)\end{array}$ & $\begin{array}{l}0.49^{* * *} \\
(0.091)\end{array}$ & $\begin{array}{l}0.42^{* * *} \\
(0.082)\end{array}$ & $\begin{array}{l}0.47^{* * *} \\
(0.088)\end{array}$ & $\begin{array}{l}0.43^{* * *} \\
(0.082)\end{array}$ \\
\hline Seat Share & $\begin{array}{l}1.29^{* * *} \\
(0.039)\end{array}$ & $\begin{array}{l}1.29^{* * *} \\
(0.039)\end{array}$ & $\begin{array}{l}1.26^{* * *} \\
(0.038)\end{array}$ & $\begin{array}{l}1.25^{* * *} \\
(0.040)\end{array}$ & $\begin{array}{l}1.31^{* * *} \\
(0.041)\end{array}$ & $\begin{array}{l}1.28^{* * *} \\
(0.041)\end{array}$ \\
\hline Seat Share ${ }^{2} / 100$ & $\begin{array}{l}0.81^{* * *} \\
(0.020)\end{array}$ & $\begin{array}{l}0.81^{* * *} \\
(0.020)\end{array}$ & $\begin{array}{l}0.82^{* * *} \\
(0.020)\end{array}$ & $\begin{array}{l}0.83^{* * *} \\
(0.021)\end{array}$ & $\begin{array}{l}0.79^{* * *} \\
(0.020)\end{array}$ & $\begin{array}{l}0.81^{* * *} \\
(0.021)\end{array}$ \\
\hline Incumbent Government & $\begin{array}{c}5.31^{* * *} \\
(0.79)\end{array}$ & $\begin{array}{c}5.31^{* * *} \\
(0.79)\end{array}$ & $\begin{array}{c}5.01^{* * *} \\
(0.74)\end{array}$ & $\begin{array}{c}4.41^{* * *} \\
(0.66)\end{array}$ & $\begin{array}{c}3.84^{* * *} \\
(0.58)\end{array}$ & $\begin{array}{c}3.62^{* * *} \\
(0.55)\end{array}$ \\
\hline Minority Government & $\begin{array}{c}0.42^{* * *} \\
(0.12)\end{array}$ & $\begin{array}{c}0.42^{* * *} \\
(0.12)\end{array}$ & $\begin{array}{l}0.50^{* *} \\
(0.15)\end{array}$ & $\begin{array}{c}0.57^{*} \\
(0.17)\end{array}$ & $\begin{array}{c}0.41^{* * *} \\
(0.12)\end{array}$ & $\begin{array}{l}0.47^{* *} \\
(0.15)\end{array}$ \\
\hline Minimum Winning Coalition & $\begin{array}{l}1.53^{* *} \\
(0.29)\end{array}$ & $\begin{array}{l}1.53^{* *} \\
(0.29)\end{array}$ & $\begin{array}{l}1.61^{* *} \\
(0.30)\end{array}$ & $\begin{array}{c}1.85^{* * *} \\
(0.35)\end{array}$ & $\begin{array}{c}1.83^{* * *} \\
(0.35)\end{array}$ & $\begin{array}{c}1.88^{* * *} \\
(0.36)\end{array}$ \\
\hline N. of Parties & $\begin{array}{l}0.26^{* * *} \\
(0.039)\end{array}$ & $\begin{array}{l}0.27^{* * *} \\
(0.039)\end{array}$ & $\begin{array}{l}0.30^{* * *} \\
(0.045)\end{array}$ & $\begin{array}{l}0.43^{* * *} \\
(0.068)\end{array}$ & $\begin{array}{c}1.30 \\
(0.24)\end{array}$ & $\begin{array}{c}1.15 \\
(0.22)\end{array}$ \\
\hline Geo. Concentration (GCI) & $\begin{array}{c}47.6^{* * *} \\
(39.5)\end{array}$ & $\begin{array}{c}50.7^{* * *} \\
(42.9)\end{array}$ & $\begin{array}{c}44.5^{* * *} \\
(37.9)\end{array}$ & $\begin{array}{c}27.0^{* * * *} \\
(22.8)\end{array}$ & $\begin{array}{c}13.1^{* * *} \\
(11.0)\end{array}$ & $\begin{array}{c}13.5^{* * *} \\
(11.4)\end{array}$ \\
\hline Independent Party & & $\begin{array}{c}0.94 \\
(0.16)\end{array}$ & $\begin{array}{l}0.63^{* *} \\
(0.12)\end{array}$ & $\begin{array}{c}0.56^{* * *} \\
(0.11)\end{array}$ & $\begin{array}{l}0.38^{* * *} \\
(0.074)\end{array}$ & $\begin{array}{l}0.37^{* * *} \\
(0.075)\end{array}$ \\
\hline Median Party (l-r) & & & $\begin{array}{c}2.16^{* * *} \\
(0.29)\end{array}$ & & & $\begin{array}{l}0.60^{* *} \\
(0.13)\end{array}$ \\
\hline Median Party (nat) & & & $\begin{array}{c}1.45^{* * *} \\
(0.18)\end{array}$ & & & $\begin{array}{l}1.45^{* *} \\
(0.25)\end{array}$ \\
\hline Wtd Dist. to Median (l-r) & & & & $\begin{array}{l}0.35^{* * *} \\
(0.039)\end{array}$ & & $\begin{array}{l}0.43^{* * *} \\
(0.077)\end{array}$ \\
\hline Wtd Dist. to Median (nat) & & & & $\begin{array}{l}0.72^{* * *} \\
(0.067)\end{array}$ & & $\begin{array}{l}1.00 \\
(0.12)\end{array}$ \\
\hline Ideol. Range (l-r) & & & & & $\begin{array}{l}0.53^{* * *} \\
(0.028)\end{array}$ & $\begin{array}{l}0.61^{* * *} \\
(0.037)\end{array}$ \\
\hline Ideol. Range (nat) & & & & & $\begin{array}{l}0.83^{* * *} \\
(0.036)\end{array}$ & $\begin{array}{l}0.87^{* * *} \\
(0.042)\end{array}$ \\
\hline $\begin{array}{l}\text { N } \\
\text { LOG LIKELIHOOD } \\
\text { No. FORM. OPP. }\end{array}$ & $\begin{array}{c}19391 \\
-1190.0 \\
489\end{array}$ & $\begin{array}{c}19391 \\
-1189.9 \\
489\end{array}$ & $\begin{array}{c}19391 \\
-1170.5 \\
489\end{array}$ & $\begin{array}{c}19391 \\
-1133.3 \\
489\end{array}$ & $\begin{array}{c}19391 \\
-1102.5 \\
489\end{array}$ & $\begin{array}{c}19391 \\
-1085.9 \\
489\end{array}$ \\
\hline
\end{tabular}




\section{B.3 Alternative Measures of Geographical Concentration}

This appendix offers the estimates of the full specifications of the models summarized in Table 7 , including the covariates not shown in the main text. The formulae of the geographical concentration indices are also displayed (see main text for the definition of each of them and for the notation used). Recall that in this robustness test the indices are later standardized when included in the conditional logit models for the sake of comparability.

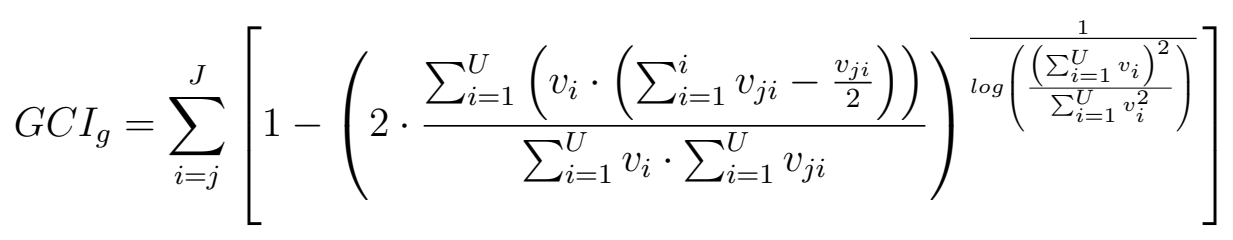

$G C I(a v .)_{g}=\sum_{i=j}^{J}\left[\frac{1}{J}\left(1-\left(2 \cdot \frac{\sum_{i=1}^{U}\left(v_{i} \cdot\left(\sum_{i=1}^{i} v_{j i}-\frac{v_{j i}}{2}\right)\right)}{\sum_{i=1}^{U} v_{i} \cdot \sum_{i=1}^{U} v_{j i}}\right) \overline{\log \left(\frac{\left(\sum_{i=1}^{U} v_{i}\right)^{2}}{\sum_{i=1}^{U} v_{i}^{2}}\right)}\right)\right]$

$G C I(\text { wtd contrib. })_{g}=\sum_{i=j}^{J}\left[\frac{s_{j}}{\sum_{j=1}^{J} s_{j}}\left(1-\left(2 \cdot \frac{\sum_{i=1}^{U}\left(v_{i} \cdot\left(\sum_{i=1}^{i} v_{j i}-\frac{v_{j i}}{2}\right)\right)}{\sum_{i=1}^{U} v_{i} \cdot \sum_{i=1}^{U} v_{j i}}\right) \frac{1}{\log \left(\frac{\left(\sum_{i=1}^{U} v_{i}\right)^{2}}{\sum_{i=1}^{U} v_{i}^{2}}\right)}\right)\right]$

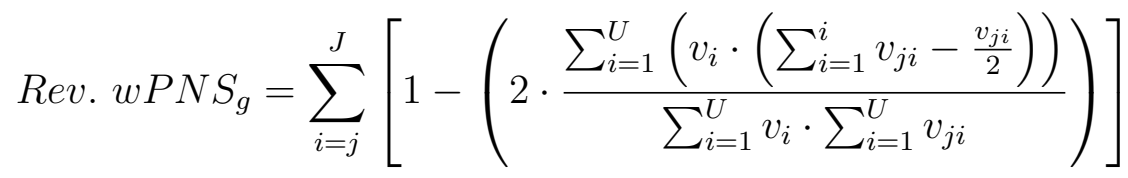

Rev. wPNS (wtd contrib. $)_{g}=\sum_{i=j}^{J}\left[\frac{s_{j}}{\sum_{j=1}^{J} s_{j}}\left(1-\left(2 \cdot \frac{\sum_{i=1}^{U}\left(v_{i} \cdot\left(\sum_{i=1}^{i} v_{j i}-\frac{v_{j i}}{2}\right)\right)}{\sum_{i=1}^{U} v_{i} \cdot \sum_{i=1}^{U} v_{j i}}\right)\right)\right]$

Gini $_{g}=\sum_{i=j}^{J}\left[1-\left(2 \cdot \frac{\sum_{i=1}^{U}\left(\sum_{i=1}^{i} v_{j i}-\frac{v_{j i}}{2}\right)}{U \cdot \sum_{i=1}^{U} v_{j i}}\right)\right]$ 
$\operatorname{Gini}(\text { wtd contrib. })_{g}=\sum_{i=j}^{J}\left[\frac{s_{j}}{\sum_{j=1}^{J} s_{j}}\left(1-\left(2 \cdot \frac{\sum_{i=1}^{U}\left(\sum_{i=1}^{i} v_{j i}-\frac{v_{j i}}{2}\right)}{U \cdot \sum_{i=1}^{U} v_{j i}}\right)\right)\right]$

Table B.3. Coalition Formation \& Geographical Concentration Robustness to Alternative Measures

\begin{tabular}{|c|c|c|c|c|c|c|c|}
\hline & $\begin{array}{l}\text { clogit } \\
(1)\end{array}$ & $\begin{array}{l}\text { clogit } \\
(2)\end{array}$ & $\begin{array}{l}\text { clogit } \\
(3)\end{array}$ & $\begin{array}{c}\text { clogit } \\
(4)\end{array}$ & $\begin{array}{c}\text { clogit } \\
(5)\end{array}$ & $\begin{array}{l}\text { clogit } \\
(6)\end{array}$ & $\begin{array}{c}\text { clogit } \\
(7)\end{array}$ \\
\hline Incumbent Party & $\begin{array}{c}0.56^{* * *} \\
(0.10)\end{array}$ & $\begin{array}{c}0.58^{* * *} \\
(0.10)\end{array}$ & $\begin{array}{c}0.57^{* * *} \\
(0.10)\end{array}$ & $\begin{array}{c}0.57^{* * *} \\
(0.10)\end{array}$ & $\begin{array}{c}0.58^{* * *} \\
(0.10)\end{array}$ & $\begin{array}{c}0.58^{* * *} \\
(0.10)\end{array}$ & $\begin{array}{c}0.58^{* * *} \\
(0.10)\end{array}$ \\
\hline Largest Party & $\begin{array}{c}2.74^{* * *} \\
(0.53)\end{array}$ & $\begin{array}{c}2.75^{* * *} \\
(0.53)\end{array}$ & $\begin{array}{c}2.93^{* * *} \\
(0.58)\end{array}$ & $\begin{array}{c}2.75^{* * *} \\
(0.53)\end{array}$ & $\begin{array}{c}2.95^{* * *} \\
(0.58)\end{array}$ & $\begin{array}{c}2.73^{* * *} \\
(0.53)\end{array}$ & $\begin{array}{c}2.93^{* * *} \\
(0.58)\end{array}$ \\
\hline Incumbent Mayor & $\begin{array}{l}0.52^{* * *} \\
(0.096)\end{array}$ & $\begin{array}{l}0.52^{* * *} \\
(0.095)\end{array}$ & $\begin{array}{l}0.52^{* * *} \\
(0.096)\end{array}$ & $\begin{array}{l}0.52^{* * *} \\
(0.096)\end{array}$ & $\begin{array}{l}0.52^{* * *} \\
(0.096)\end{array}$ & $\begin{array}{l}0.52^{* * *} \\
(0.095)\end{array}$ & $\begin{array}{l}0.52^{* * *} \\
(0.096)\end{array}$ \\
\hline Seat Share & $\begin{array}{l}1.29^{* * *} \\
(0.039)\end{array}$ & $\begin{array}{l}1.29^{* * *} \\
(0.039)\end{array}$ & $\begin{array}{l}1.29^{* * *} \\
(0.040)\end{array}$ & $\begin{array}{l}1.29^{* * *} \\
(0.039)\end{array}$ & $\begin{array}{l}1.29^{* * *} \\
(0.039)\end{array}$ & $\begin{array}{l}1.29^{* * *} \\
(0.039)\end{array}$ & $\begin{array}{l}1.29^{* * *} \\
(0.039)\end{array}$ \\
\hline Seat Share ${ }^{2} / 100$ & $\begin{array}{l}0.81^{* * *} \\
(0.020)\end{array}$ & $\begin{array}{l}0.81^{* * *} \\
(0.020)\end{array}$ & $\begin{array}{l}0.80^{* * *} \\
(0.020)\end{array}$ & $\begin{array}{l}0.81^{* * *} \\
(0.020)\end{array}$ & $\begin{array}{l}0.81^{* * *} \\
(0.020)\end{array}$ & $\begin{array}{l}0.81^{* * *} \\
(0.020)\end{array}$ & $\begin{array}{l}0.81^{* * *} \\
(0.020)\end{array}$ \\
\hline Incumbent Government & $\begin{array}{c}5.31^{* * *} \\
(0.79)\end{array}$ & $\begin{array}{c}5.38^{* * *} \\
(0.80)\end{array}$ & $\begin{array}{c}5.35^{* * *} \\
(0.80)\end{array}$ & $\begin{array}{c}5.36^{* * *} \\
(0.80)\end{array}$ & $\begin{array}{c}5.37^{* * *} \\
(0.80)\end{array}$ & $\begin{array}{c}5.37^{* * *} \\
(0.80)\end{array}$ & $\begin{array}{c}5.37^{* * *} \\
(0.80)\end{array}$ \\
\hline Minority Government & $\begin{array}{c}0.42^{* * *} \\
(0.12)\end{array}$ & $\begin{array}{c}0.44^{* * *} \\
(0.13)\end{array}$ & $\begin{array}{c}0.44^{* * *} \\
(0.13)\end{array}$ & $\begin{array}{c}0.43^{* * *} \\
(0.13)\end{array}$ & $\begin{array}{c}0.44^{* * *} \\
(0.13)\end{array}$ & $\begin{array}{c}0.43^{* * *} \\
(0.13)\end{array}$ & $\begin{array}{c}0.44^{* * *} \\
(0.13)\end{array}$ \\
\hline Minimum Winning Coalition & $\begin{array}{l}1.53^{* *} \\
(0.29)\end{array}$ & $\begin{array}{l}1.52^{* *} \\
(0.28)\end{array}$ & $\begin{array}{l}1.52^{* *} \\
(0.28)\end{array}$ & $\begin{array}{l}1.56^{* *} \\
(0.29)\end{array}$ & $\begin{array}{l}1.54^{* *} \\
(0.29)\end{array}$ & $\begin{array}{l}1.54^{* *} \\
(0.29)\end{array}$ & $\begin{array}{l}1.52^{* *} \\
(0.28)\end{array}$ \\
\hline N. of Parties & $\begin{array}{l}0.26^{* * *} \\
(0.039)\end{array}$ & $\begin{array}{l}0.36^{* * *} \\
(0.045)\end{array}$ & $\begin{array}{l}0.37^{* * *} \\
(0.045)\end{array}$ & $\begin{array}{l}0.28^{* * *} \\
(0.046)\end{array}$ & $\begin{array}{l}0.37^{* * *} \\
(0.046)\end{array}$ & $\begin{array}{l}0.28^{* * *} \\
(0.046)\end{array}$ & $\begin{array}{l}0.37^{* * *} \\
(0.046)\end{array}$ \\
\hline GCI (std) & $\begin{array}{c}1.97^{* * *} \\
(0.29)\end{array}$ & & & & & & \\
\hline GCI (av.) (std) & & $\begin{array}{c}1.34^{* * *} \\
(0.14)\end{array}$ & & & & & \\
\hline GCI (wtd contrib.) (std) & & & $\begin{array}{c}1.48^{* * *} \\
(0.18)\end{array}$ & & & & \\
\hline Rev. wPNS (std) & & & & $\begin{array}{c}1.58^{* * *} \\
(0.24)\end{array}$ & & & \\
\hline Rev. wPNS (wtd contrib.) (std) & & & & & $\begin{array}{l}1.37^{* *} \\
(0.19)\end{array}$ & & \\
\hline Gini (std) & & & & & & $\begin{array}{c}1.60^{* * *} \\
(0.25)\end{array}$ & \\
\hline Gini (wtd contrib.) (std) & & & & & & & $\begin{array}{l}1.35^{* *} \\
(0.19)\end{array}$ \\
\hline $\mathrm{N}$ & 19,391 & 19,391 & 19,391 & 19,406 & 19,406 & 19,391 & 19,391 \\
\hline LOG LIKELIHOOD & -1190.0 & -1197.7 & -1197.4 & -1199.1 & -1201.1 & -1197.4 & -1199.5 \\
\hline NO. FORM. OPP. & 489 & 489 & 489 & 490 & 490 & 489 & 489 \\
\hline
\end{tabular}




\section{B.4 Binary Logit Models}

This appendix offers the estimates of the full specifications of the models summarized in Table 8 , including the covariates not shown in the main text.

Table B.4. Coalition Formation \& Geographical Concentration Robustness TO BinaRY LOGits

\begin{tabular}{|c|c|c|c|c|c|}
\hline & $\begin{array}{l}\text { clust s.e. } \\
\text { (1) }\end{array}$ & $\begin{array}{l}\text { form. opp. FE } \\
(2)\end{array}$ & $\begin{array}{c}\text { Dichot. IV } \\
(3)\end{array}$ & CE match. & CE match. $(\mathrm{k} 2 \mathrm{k})$ \\
\hline Incumbent Party & $\begin{array}{l}2.23^{* * *} \\
(0.31)\end{array}$ & $\begin{array}{l}2.16^{* * *} \\
(0.27)\end{array}$ & $\begin{array}{l}2.24^{* * *} \\
(0.30)\end{array}$ & $\begin{array}{l}2.17^{* * *} \\
(0.30)\end{array}$ & $\begin{array}{l}1.64^{* *} \\
(0.39)\end{array}$ \\
\hline Largest Party & $\begin{array}{c}6.40^{* * *} \\
(1.33)\end{array}$ & $\begin{array}{c}5.25^{* * *} \\
(1.11)\end{array}$ & $\begin{array}{c}6.27^{* * *} \\
(1.30)\end{array}$ & $\begin{array}{c}6.66^{* * *} \\
(1.85)\end{array}$ & $\begin{array}{c}6.27^{* * *} \\
(3.87)\end{array}$ \\
\hline Incumbent Mayor & $\begin{array}{l}0.26^{* * *} \\
(0.053)\end{array}$ & $\begin{array}{l}0.28^{* * *} \\
(0.054)\end{array}$ & $\begin{array}{l}0.26^{* * *} \\
(0.052)\end{array}$ & $\begin{array}{l}0.20^{* * *} \\
(0.052)\end{array}$ & $\begin{array}{c}0.095^{* * *} \\
(0.061)\end{array}$ \\
\hline Seat Share & $\begin{array}{c}1.00 \\
(0.014)\end{array}$ & $\begin{array}{c}0.97^{*} \\
(0.017)\end{array}$ & $\begin{array}{c}1.00 \\
(0.014)\end{array}$ & $\begin{array}{l}1.05^{* * *} \\
(0.017)\end{array}$ & $\begin{array}{c}1.08^{* *} \\
(0.036)\end{array}$ \\
\hline Seat Share ${ }^{2} / 100$ & $\begin{array}{c}1.05 \\
(0.031)\end{array}$ & $\begin{array}{c}1.11^{* *} \\
(0.045)\end{array}$ & $\begin{array}{c}1.05 \\
(0.031)\end{array}$ & $\begin{array}{c}0.95 \\
(0.034)\end{array}$ & $\begin{array}{c}0.91 \\
(0.071)\end{array}$ \\
\hline Geo. Concentration (GCI) & $\begin{array}{c}18.5^{* * *} \\
(12.0)\end{array}$ & $\begin{array}{c}13.5^{* * *} \\
(13.6)\end{array}$ & & & \\
\hline High GCI (>p90) & & & $\begin{array}{l}1.37^{* *} \\
(0.20) \\
\end{array}$ & $\begin{array}{l}1.35^{* *} \\
(0.19) \\
\end{array}$ & $\begin{array}{c}1.64^{* * *} \\
(0.31) \\
\end{array}$ \\
\hline $\begin{array}{l}\text { N } \\
\text { LOG LIKELIHOOD } \\
\text { No. FORM. OPP. }\end{array}$ & $\begin{array}{c}2445 \\
-1457.4 \\
489\end{array}$ & $\begin{array}{c}2418 \\
-842.5 \\
482\end{array}$ & $\begin{array}{c}2449 \\
-1466.0 \\
490\end{array}$ & $\begin{array}{c}2177 \\
-1216.6 \\
490\end{array}$ & $\begin{array}{c}480 \\
-296.3 \\
293\end{array}$ \\
\hline
\end{tabular}

Exponentiated coefficients; Standard errors in parentheses

${ }^{*} p<0.10,{ }^{* *} p<0.05,{ }^{* * *} p<0.01$ 


\section{Party Positions}

The first robustness check provided in the paper attempts to control for the role of ideology in government formation. As mentioned, the main obstacle lies in the absence of reliable data on the positioning, within the conventional ideological spectrum, of Catalan parties at the local level. Two strong assumptions are then required. Firstly, all independent parties, namely those without an explicit organizational connection to a specific nation- or region-wide party, are placed in the middle of both the left-right and Spanish-Catalan nationalism dimensions ( 5 in a scale ranging from 0 to 10). Secondly, for the rest of the parties it is assumed that they all share the exact same position as the nation- or region-wide party they are linked with. Table C.1 shows the positions used in the analyses for each party, which are averages of parties' positions (as perceived by citizens over rather long data series) drawn from the Spanish Centre for Sociological Research. 


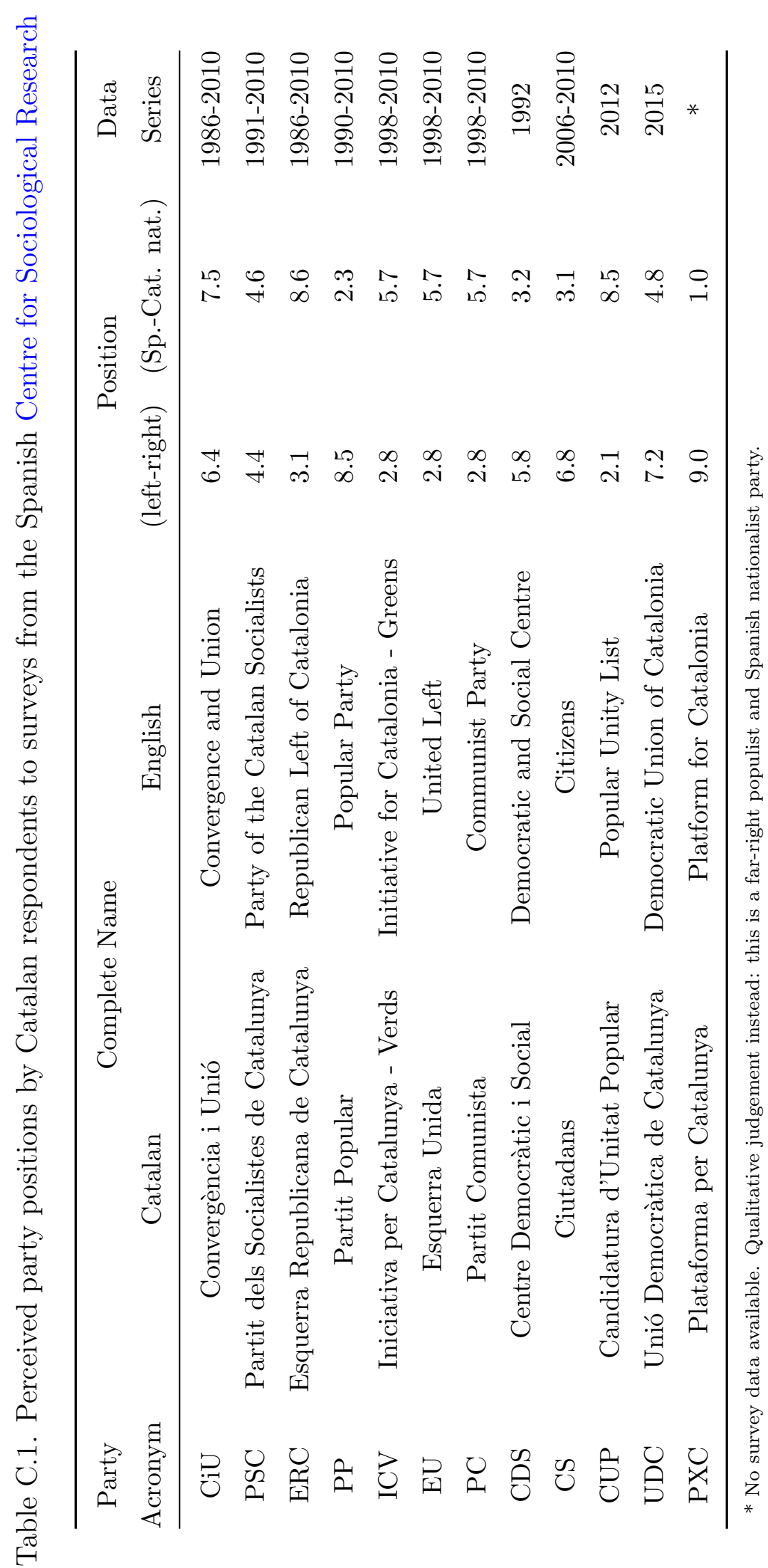

